\title{
FENOMENA PERKAWINAN BEDA AGAMA DI INDONESIA DITINJAU DARI PERSPEKTIF ALQURAN DAN HADITS
}

\author{
Arsal \\ Fakultas Syariah LAIN Bukittinggi \\ e-mail:arsal90@gmail.com
}

Diterima: 2 November 2018

Direvisi : 1 Desember 2018

Diterbitkan: 31 Desember 2018

\begin{abstract}
Cases of interfaith marriages in a pluralist population are something that is difficult to stem. This is confirmed by the data obtained in the eighties, there were 825 cases. This phenomenon occurs when the Indonesian people have special regulations regarding marriage, namely Law No. 1 of 1974. It's just that the law does not explicitly explain in this special article the prohibition on marriage. This prohibition on marriage is found in the Compilation of Islamic Law (KHI), precisely Articles 40 and 44. Nevertheless, the marriage still occurs because the government issued its legal umbrella, namely jurisprudence marked by the issuance of a Supreme Court (MA) Decree number: 1400 k / Pdt / 1986 which is considered as a legal policy to anticipate the legal vacuum. Along with that, in the context of Islamic law in Indonesia, there are opinions of scholars / experts who are pro and contra of marriage like this. Based on these problems, the focus of the research in this paper is to find out how this marital status is extracted from the Qur'an and Hadith. This study focuses on library research (library research) by using inductive, deductive, and comparative thinking methods. Furthermore, to find answers in the context of Islamic law, this study uses three approaches as a basis for analysis, namely; First, the Socio-Historical Approach. Second, Content Analysis Approach (content analysis). Third, the fiqh approach (the results of the Normative Legalistic Approach. The results show that the religions that develop and are embraced by the citizens of Indonesia can be positioned as ahl al-kitâb. The marriage laws carried out by Indonesian citizens of different beliefs, both male and female mubah (allowed) during the marriage is fulfilled the inner criterion, namely muhshanat ...
\end{abstract}

\section{Key Words: Interfaith-Indonesian marriage, Al-Qur'an and Hadith}

\section{Abstrak}

Kasus perkawinan beda agama di Indonesia yang berpenduduk pluralis sesuatu yang sulit untuk dibendung. Hal ini dibukitkan dengan data yang diperoleh di era delapan puluhan terdapat 825 kasus. Fenomena ini terjadi ketika bangsa Indonesia telah mempunyai regulasi khusus tentang perkawinan, yakni Undang-Undang No. 1 Tahun 1974. Hanya saja undangundang tidak menjelaskan secara tegas dalam pasal khusus tentang larangan perkawinan ini. Larangan perkawinan seperti ini ada dijumpai dalam Kompilasi Hukum Islam (KHI), tepatnya Pasal 40 dan 44. Meskipun demikian, perkawinan itu tetap saja terjadi karena pemerintah mengeluarkan payung hukumnya, yakni yurisprudensi yang ditandai dengan keluarnya Surat Keputusan Mahkamah Agung (MA) nomor: 1400 k/Pdt/1986 yang dianggap sebagai kebijakan hukum untuk mengantisipasi kevakuman hukum. Seiring dengan itu, dalam konteks hukum Islam di Indonesia dijumpai pendapat ulama/pakar yang pro dan kontra terhadap perkawinan seperti ini. Berdasarkan permasalahan ini, maka fokus penelitian dalam tulisan ini menemukan bagaimana status perkawinan ini yang digali dari al-Qur'an dan Hadits. Kajian ini menitik beratkan kepada penelitian kepustakaan (library research) dengan menggunakan metode berfikir induktif, deduktif, dan komperatif. Selanjutnya untuk menemukan jawaban dalam konteks hukum Islam, maka penelitian ini menggunakan tiga pendekatan sebagai dasar analisis, yaitu; Pertama, Pendekatan Sosio-Historik. Kedua, Pendekatan Content Analisis (analisis isi). Ketiga, Pendekatan fiqh (Normative Legalistic Approach. Hasil penelitian menunjukkan bahwa 
agama-agama yang berkembang dan dianut oleh warga Indonesia dapat diposisikan sebagai abl al-kitâb. Adapun hukum perkawinan yang dilakukan oleh penduduk Indonesia yang berbeda keyakinan, baik laki-laki maupun perempuan hukumnya mubah (boleh) selama yang melangsungkan perkawinan terssbut memenuhi kriteri dalam, yakni mubshanat..

Kata Kunci: Perkawinan beda agama- Indonesia- Alquran dan Hadits

\section{Latar Belakang}

Indonesia adalah salah satu negara yang penduduknya pluralistik dengan beragam etnis, suku, sosial, agama ${ }^{1}$ dan budaya yang berbeda. Hal ini tercermin dari semboyan bangsa Indonesia yaitu Bhinneka Tunggal Ika (Persatuan dalam Keragaman). Dalam kondisi keberagaman seperti ini, suatu hal yang sulit dihindari adalah terjadinya interaksi sosial di antara kelompok-kelompok masyarakat yang berbeda tersebut dan pada akhirnya akan berlanjut pada ikatan perkawinan.

Perkawinan merupakan peristiwa sakral yang sangat penting dalam masyarakat. Dengan hidup bersama, kemudian melahirkan keturunan yang merupakan sendi utama bagi pembentukan negara dan bangsa. ${ }^{2}$ Mengingat pentingnya peranan hidup bersama, pengaturan mengenai perkawinan memang sesuatu yang sangat urgen ditangani oleh negara. Di sini, negara berperan untuk melegalkan ikatan perkawinan yang terjalin antara seorang pria dan wanita dalam kondisi keberagaman serta laju dinamika kehidupan yang sulit dibendung.

Seiring dengan dinamika kehidupan masyarakat modern, permasalahan yang terjadi semakin kompleks. Berkaitan dengan

${ }^{1}$ Pada Pasal 1 Peraturan Pemerintah Republik Indonesia No: I/PNPS/1965 tentang Pencegahan Penyalahgunaan dan atau Penodaan Agama, sesuai dengan LN RI Tahun 1965 Nomor 3 pada Tanggal 27 Jan 1965 dijelaskan bahwa agama yang dipeluk penduduk Indonesia adalah: Islam, Kristen, Katolik, Hindu, Budha, dan Konghucu (Confusius).

2 Soedharyo Soimin, Hukum Orang dan Keluarga, (Jakarta: Sinar Grafika, 2002), h. 3 perkawinan, belakangan ini sering tersiar dalam berbagai media terjadinya perkawinan yang dianggap problematis dalam kehidupan bermasyarakat, seperti perkawinan beda agama.Perkawinan beda agama yang masih belum diterima dengan baik oleh masyarakat, biasanya salah satu pihak dari pasangan tersebut berpindah agama atau mengikuti agama salah satu pihak sehingga perkawinannya pun disahkan berdasarkan agama yang dipilih tersebut. Bahkan di tengah-tengah masyarakat, pro-kontra pendapat terjadi sehubungan dengan perkawinan beda agama ini. Salah satu pendapat mengatakan bahwa masalah agama merupakan masalah pribadi sendiri-sendiri ${ }^{3}$ sehingga negara tidak perlu melakukan pengaturan yang memasukkan unsur-unsur agama. Namun, di pihak lain, ada yang berpendapat bahwa perkawinan beda agama dilarang oleh agama sehingga tidak dapat diterima. ${ }^{4}$

Selanjutnya, di dalam kehidupan berbangsa dan bernegara, telah terjadi perubahan yang signifikan dalam pembentukan hukum dan perundangundangan, terutama dalam hal penegakan Hak-Hak Asasi Manusia (HAM). Aspekaspek dalam HAM terus menjadi sorotan masyarakat dunia karena semakin timbul kesadaran bahwa muatannya merupakan bagian inheren dari kehidupan dan jati diri manusia.

\footnotetext{
3

Lihat

bttp:/ / buk.umonline.com/detail.asp.id=Berita. (diakses tanggal 7 November 2012

4 Hafiz Anshary, Problematika Hukum Islam

Kontemporer, (Jakarta: Pustaka Firdaus, 1996), h. 17-18
} 
Ketika menyikapi dinamika dan keberagaman keyakinan/kepercayaan dan cultur (budaya) masyarakat yang berbeda, negara Indonesia telah mempunyai sejarah panjang dan juga telah merespon bagaimana kondisi sosial masyarakat ketika menelorkan hukum dan perundang-undangan, di antaranya berkaitan dengan peraturan perundang-undangan tentang perkawinan. Dalam hal perkawinan, negara Indonesia semenjak tahun 1974 telah memiliki undang-undang khusus yang dijadikan pedoman bagi masyarakat untuk melangsungkan perkawinan, yakni UU No.1 Tahun 1974. Undang-undang No.1 tahun 1974 ini dijadikan dasar dan acuan bagi masyarakat Indonesia untuk melangsungkan suatu perkawinan dan sekaligus menentukan tentang keabsahan suatu perkawinan yang dilakukan oleh penduduk Indonesia. ${ }^{5}$

Terlepas dari latar belakang tidak diaturnya secara eksplisit perkawinan beda agama di Indonesia, namun secara realitas telah memicu perbedaan penafsiran hukum. Ada pendapat yang mengatakan bahwa perkawinan beda agama tidak sah karena bertentangan dengan UU No. 1 Tahun 1974 Pasal 2 ayat1 jo Pasal 8 f. Ada pula pendapat yang kontra dengan pendapat sebelumnya, bahwa perkawinan beda agama tidak bertentangan dengan UU No. 1 Tahun 1974, artinya dapat disamakan dengan Pasal 57 tentang kawin campuran. Terakhir ada pula pendapat dengan persi

5 Dalam Undang-Undang Nomor 1 Tahun 1974 dinyatakan tentang keabsahaan suatu perkawinan, seperti dituangkan pada Pasal 2 ayat 1 bahwa perkawinan adalah sah, apabila dilakukan menurut hukum masing-masing agamanya dan kepercayaan itu. Selanjutnya pada Pasal 10 PP No. 9 Tahun 1975 dinyatakan bahwa perkawinan baru sah jika dilakukan di hadapan pegawai pencatat dan dihadiri dua orang saksi. Lihat Tim Citra Umbara, UNDANG-UNDANG REPUBLIK INDONESLA NOMOR 1 TAHUN 1974 Tentang PERKAWINAN DAN KOMPILASI HUKUM ISLAM, (Bandung: Citra Umbara, 2010), Cet. V, h. 2 dan 45 lain yang mengatakan bahwa perkawinan tersebut tidak ada diatur dalam UndangUndang No.1 Tahun 1974, maka mesti merujuk kepada Pasal 66. ${ }^{6}$ Dan bila dikatakan undang-undang tidak ada mengatur tentang perkawinan beda agama, maka hal ini berarti telah terjadi kekosongan hukum. Pada prinsipnya dalam negara hukum tidak dibenarkan adanya kekosongan hukum, karena kondisi seperti ini akan berdampak negatif dalam kehidupan masyarakat dan apa yang dilakukan masyarakat tidak mempunyai kekuatan hukum yang kuat/pasti.

Meskipun demikian, ketentuan perkawinan beda agama di Indonesia secara konkrit ditemukan dalam KHI (Kompilasi Hukum Islam), tepatnya Pasal 40 point (c), yaitu; "Dilarang melangsungkan perkawinan antara seorang pria dengan seorang wanita yang tidak beragama Islam". Selanjutnya terdapat pula dalam Pasal 44, yakni; "Seorang wanita Islam dilarang melangsungkan perkawinan dengan seorang pria yang tidak beragama Islam". 7 Namun demikian, perkawinan beda agama di Indonesia masih tetap juga terjadi. Memang perlu disadari bahwa KHI tidak punya kekuatan hukum mengikat, sebab kehadiran KHI hanya sebagai pegangan dan referensi bagi hakim ketika menetapkan hukum agar terwujud keseragaman.

Dengan demikian regulasi perkawinan beda agama di negara Indonesia menurut kacamata hukum telah terjadi kevacuman hukum (kekosongan hukum). Untuk mengisi kekosongan hukum tersebut serta merespon kenyataan yang terjadi di tengah-tengah masyarakat Indonesia, maka Mahkamah Agung (MA) dalam

${ }^{6}$ Hafiz Anshary, Op.Cit, h. 16-17

7 Tim Citra Umbara, Undang-Undang Republike Indonesia Tabun 1974 Tentang Perkawinan dan Kompilasi Hukum Islam, (Bandung: Citra Umbara, 2010), Cet. V, h. 241-242 
yurisprudensinya tanggal 20 Januari 1989 Nomor: 1400 K/Pdt/1986, memberikan solusi hukum bagi perkawinan beda agama yang berisi bahwa perkawinan beda agama dapat diterima permohonannya di Kantor Catatan Sipil sebagai satu-satunya instansi yang berwenang untuk melangsungkan permohonan yang kedua calon suami isteri tidak beragama Islam untuk wajib menerima permohonan perkawinan beda agama tersebut. $^{8}$

Bentuk lain untuk melakukan perkawinan beda agama dapat dilakukan dengan cara melakukan perkawinan bagi pasangan yang berbeda agama tersebut di luar negeri. Berdasarkan pada Pasal 56 UU 1/1974 yang mengatur perkawinan di luar negeri, dapat dilakukan oleh sesama warga negara Indonesia, dan perkawinan antar pasangan yang berbeda agama tersebut adalah sah bila dilakukan menurut hukum yang berlaku di negara di mana perkawinan itu berlangsung. Setelah suami isteri itu kembali di wilayah Indonesia, paling tidak dalam jangka waktu satu tahun surat bukti perkawinan dapat didaftarkan di kantor pencatatan perkawinan tempat tinggal mereka. Artinya, perkawinan yang dilakukan oleh pasangan suami isteri yang berbeda agama tersebut adalah sah karena dapat diberikan akta perkawinan. ${ }^{9}$

Pertimbangan lain dari MA (Mahkamah Agung) untuk mengeluarkan keputusan ini adalah bahwa pasangan yang akan melangsungkan perkawinan itu secara sadar telah menginginkan perkawinannya dilaksanakan tidak lagi sesuai menurut kepercayaan/agama yang mereka anut. Artinya mereka menginginkan perkawinan

8 Soedharyo Soimin, Hukum Orang dan Keluarga, (Jakarta: Sinar Grafika, 2002), h. 96

${ }^{9}$ Ibid, h. 97 dan Himpunan Yurisprudensi Tentang Hukum Perdata, (Jakarta: Sinar Grafika, 1996), h. 56 itu dilaksanakan diluar dari ketentuan agama yang mereka anut. ${ }^{10}$

Sebagian dari argumentasi dan pertimbangan yang dibangun oleh MA (Mahkamah Agung) untuk menerima Kasasi pemohon sehingga yang bersangkutan dapat melangsungkan perkawinan beda agama di kantor catatan sipil, menurut hemat penulis hal ini tidak dapat dibenarkan sebab alur fikiran MA (Mahkamah Agung) menetapkan pertimbangan seperti ini tidak mencerdaskan masyarakatnya terhadap agama yang mereka anut dan sekaligus juga telah melanggar semangat UUD $1945^{11}$ dan dasar negara Republik Indonesia. ${ }^{12}$

Selanjutnya, fenomena perkawinan beda agama yang terjadi di Indonesia juga memunculkan pandangan yang berbeda dikalangan pakar/ulama dan ormas Islam di Indonesia. Majelis Ulama Indonesia (MUI) umpamanya, dalam Musyawarah Nasional VII MUI, pada 19-22 Jumadil Akhir 1426 H./26-29 Juli 2005 M., menetapkan: Pertama, perkawinan beda agama hukumnya haram dan tidak sah. Kedua, perkawinan antara seorang muslim dengan wanita ablalkitâb adalah haram dan tidak sah. ${ }^{13}$

Pendapat yang lebih kontroversial dan menantang dari pendapat-pendapat di

${ }^{10}$ Keputusan MA (Mahkamah Agung) Nomor: $1400 \mathrm{~K} / \mathrm{Pdt} / 1986$ dilatar belakangi oleh permohonan Kasasi oleh Andi Vonny Gani P yang beragama Islam ingin melangsungkan perkawinan dengan seorang lakilaki bernama Andrianus Petrus Hendrik Nelwan yang beragama Kristen Protestan.

11 Dalam Pasal 29 ayat 1 dan 2 UUD 1945 dijelaskan bahwa Negara Indonesia berdasar atas Ketuhanan Yang Maha Esa dan Negara menjamin kemerdekaan tiap-tiap penduduk untuk memeluk agamanya masing-masing dan untuk beribadat menurut agamanya dan kepercayaannya itu (Redaksi Indonesia Tera, UUD 1945 Dan Perubahannya + Struktur Ketatanegaraan, (Yogyakarta: Indonesia Tera, 2010), Cet. VII, h. 36)

12 Sila Pertama dalam Pancasila berbunyi;

Ketuhanan Yang Maha Esa

${ }_{13}$ Majelis Ulama Indonesia, Himpunan Keputusan dan fatwa Majelis Ulama Indonesia, (Jakarta: Sekretariat Majelis Ulama Indonesia Masjid Istiqlal, 1995), h. 91 
atas dikemukakan oleh kelompok yang menamakan dirinya JIL (Jaringan Islam Liberal). Menurut Ulil Abshar Abdalla (koordinator JIL), mengatakan bahwa larangan perkawinan lintas agama sudah tidak relevan lagi. Menurutnya, al-Quran juga tidak pernah secara tegas melarang hal itu, karena al-Quran menganut pandangan universal tentang martabat manusia yang sederajat, tanpa melihat perbedaan agama. Segala produk hukum Islam klasik yang membedakan kedudukan orang Islam dan non-Islam harus diamandemen berdasarkan prinsip kesederajatan universal dalam tataran kemanusiaan. ${ }^{14}$

Terlepas dari adanya pendapat yang melarang dan membolehkan, fakta dilapangan menunjukkan bahwa perkawinan beda agama di Indonesia masih saja terjadi sampai saat ini dan sulit untuk dibendung, meskipun perkawinan ini dianggap problematik secara sosial dan hukum.

Hal seperti ini tentu saja tidak baik dibiarkan dalam kehidupan berbangsa dan bernegara. Sehubungan dengan kasus-kasus perkawinan beda agama ini perlu penanganan serius dan diatur secara jelas dalam konteks negara Indonesia. Sebab jika merujuk kepada ketentuan ajaran agama Islam yang bersumberkan kepada al-Qur an dan Sunnah sebenarnya telah menjelaskan tentang kebolehan untuk melangsungkan perkawinan beda agama tersebut di Indonesia.

Dalam al-Qur`an dijumpai beberapa ayat-ayat yang menginformasikan terkait perkawinan beda agama tersebut. Pada satu sisi dijumpai ayat yang melarang umat Islam, baik laki-laki maupun perempuan untuk melangsungkan perkawinan dengan kelompok musyrikat dalam kondisi dan situasi bagaimanapun juga. Pada sisi lain

14 Ulil Abshar Abdalla, Menyegarkan Kembali Pemahaman Islam, Kompas. Senin, 18 November 2002. dijumpai pula firman Allah yang berisi tentang kebolehan bagi umat Islam untuk melangsungkan perkawinan dengan kelompok kitabiyat atau abl al-kitâb.

Di samping istilah abl al-kitâb, alQur`an juga memakai istilah utu al-kitab,alladzina atainabumulkitab, al-Ladzina hadu, utu nashiban minal kitab, al-Yabud. Muhammad Fuad Abdul al-Baqi telah mengklasifikasikan dalam kitabnya tentang jumlah surat-surat dan ayat-ayat al-Qur`an yang memuat ketiga komunitas tersebut di atas, antara lain: Pertama, kata abl al-kitâb terulang dalam al-Qur'an sebanyak 31 kali yang tergelar dalam 9 surat. ${ }^{15} \mathrm{Kedua}$, kata utu al-kitab terulang dalam al-Qur’an sebanyak 21 kali yang tergelar dalam 8 surat. ${ }^{16}$ Ketiga, kata alladrina atainahum al-Kitab terulang dalam al-Qur`an sebanyak 10 kali yang tergelar dalam 8 surat. ${ }^{17}$ Keempat, al-Ladzina hadu sebanyak 10 kali. Kelima, an-Nashara sebanyak 14 kali, dan Bani/Banu Israil sebanyak 40 kali.

Ketika mengkompromikan dari aspek nuzul dan pemahaman hukum yang terkandung dalam kedua ayat di atas memicu keragaman pendapat para ulama, baik dikalangan ulama Sunni, ulama Syi'i, dan ulama Zhahiri. Objek perbedaan pendapat itu berkaitan dengan cakupan makna yang terkandung dalam istilah abl alkitâb dan juga dalam hal menetapkan hukum perkawinan antara muslim dengan kelompok tersebut.

Berkaitan dengan cakupan makna abl al-kitâb, terdapat keragaman pendapat dikalangan ulama Sunni, di antaranya; Imam Syafi'i mengatakan bahwa abl al-kitâb itu

${ }^{15}$ Muhammad Fuad Abdul al-Baqi, Al-Mu'jam al-Mafahras li al-Faaz̧h al-Qur'an, (Beirut: Dâr al-Fikr, 1987), h. 121-122

16 Muhammad Fuad Abdul al-Baqi, al-Mujam ...., h. 14

${ }^{17}$ Muhammad Fuad Abdul al-Baqi, al-Mu'jam ...., h. 12 
adalah Yahudi dan Nasrani dari keturunan Bani Israil, tidak termasuk bangsa-bangsa lain meskipun mereka menganut agama Yahudi dan Nasrani. Pendapat beliau ini antara lain didasari kepada teks ayat yang berbunyi "min qablikum" artinya sebelum kamu. Di samping itu juga dengan pertimbangan bahwa Nabi Musa dan Nabi Isa hanya diutus Tuhan kepada bangsa Bani Israil bukan kepada bangsa-bangsa lain. ${ }^{18}$

$$
\text { Pendapat yang berbeda }
$$

dikemukakan oleh tokoh mazhab yang beraliran ra'yu, yaitu imam Abu Hanifah. Menurut Abu Hanifah abl al-kitâb adalah orang-orang yang mempercayai salah seorang nabi-nabi atau kitab-kitab yang pernah diturunkan Allah Swt. Dengan demikian abl al-kitâb bukan tertuju kepada kelompok Yahudi dan Nasrani saja, akan tetapi juga diberlakukan kepada kelompok yang percaya kepada shubuf Ibrahim atau kitab Zabur yang diturunkan kepada Nabi Daud as. Lebih lanjut beliau memposisikan sebahagian penganut agama Shabiah ke dalam kelompok abl al-kitâb, dengan pertimbangan kelompok ini pernah membaca kitab Zabur sekalipun mereka dalam berkeyakinan menyembah malaikat. ${ }^{19}$

Seorang pakar tafsir kontemporer yang bercorak al-Adaby wa al-Ijtima'iy (sosiokultural kemasyarakat) bernama Muhammad Rasyid Ridha memberikan batasan yang luas terhadap pengertian dari kata abl al-kitâb itu. Menurut beliau penganut agama Majusi, Shabìin,

18 Muhammad ibn Idris al-Syafi'i, Al-Umm, (Beirut: Dâr al-Fikr, tt), Juz. V, h. 6. Dan bandingkan 'Imaduddin Abi Fidaa' Ismail Ibn Umar ibn Katsir alQarsy ad-Dimasyiqy, Tafsir al-Qur'an al-'Azhim, selanjutnya disebut Tafsir Ibn Katsir, (Riyad: Dâr al-Salam Linasyri wa Tawzi', 1418), h. 400

19 Ismail Haqiy al-Baruszi, Tafsir al-Rûh alBayân, (Beirut: Dâr al-Fikr, tt), Jld. II, h. 348 dan Bandingkan Abi Bakar Ahmad ar-Razi al-Jashash, Abkam al-Quran, selanjutnya disebut Tafsir al-Jashash, (Beirut: Dâr al-Fikr, 1993), Jld. I, h. 464 penyembah berhala di India dan Cina, penganut agama Hindu dan agama Budha, serta penganut agama yang serupa, seperti agama Sinto di Jepang semuanya itu digolongkan kepada abl al-kitâb. Agamaagama tersebut menurut beliau pada awalnya merupakan agama tauhid sampai sekarang dan memiliki kitab suci, sebab berdasarkan kepada penjelasan al-Qur`an bahwa semua umat telah diutus oleh Allah kepada mereka seorang rasul dan membawa kitab samawi. Namun dalam perjalanan sejarah agama tersebut telah dipengaruhi oleh ajaran luar yang bersifat syirik, seperti Paganisme. ${ }^{20}$ Pendapat Ridha ini memandang abl al-kitâb itu dari pendekatan agama yang berkembang, bila penganutnya memiliki kitab suci dalam menjalankan agamanya maka dapat digolongkan abl alkitâb.

Demikian beberapa pemikiran dan pendapat ulama yang berkembang diseputar cakupan makna dari abl al-kitâb yang disebut dalam al-Qur`an. Memperhatikan pendapat ulama-ulama mazhab di atas dapat diklasifikasikan; Pertama, pendapat yang memberikan pemaknaan yang sempit sesuai dengan makna teks. Kedua, pendapat yang memaknainya dengan luas, artinya bukan semata tertumpu kepada pemahaman makna teks saja, akan tetapi berpedoman agak jauh kepada substansi dari sebuah ajaran atau agama yang dianut oleh setiap manusia.

Selanjutnya, terkait dengan hukum perkawinan antara muslim dengan abl alkitâb/kitabiyat, dikalangan ulama-ulama mazhab (Sunni, Syi'i, dan Zhahiri) terdapat perbedaan pendapat yang saling kontradiktif antara satu sama lainnya yang tentu saja

20 Rasyid Ridha, Tafsir al-Qur'an al-Hakim, selanjutnya disebut Tafsir al-Manâr, (Mesir: Mathba'ah Muhammad Ali Shabih wa Auladuhu al-Azhar, tt), Juz. VI, Cet. II, h. 193 
pendapat tersebut didukung dan dikuatkan dengan beberapa dalil-dalil dan argumentasi.

Mayoritas Ulama Sunni (jumhur ulama) berpendapat bahwa laki-laki muslim dibolehkan menikah dengan wanita Yahudi dan Nasrani (abl al-kitâb), dengan salah satu pertimbangan bahwa teks "musyrikat" tidak tercakup padanya abl al-kitâb, walaupun karakter mereka sama-sama dengan orangorang musyrik, yaitu tiada menginginkan diturunkannya kebaikan sebagaimana dijelaskan Allah dalam surat al-Baqarah ayat 105, pada ayat ini Allah meng'athafkan (menghubungkan) lafaz "musyrikin" kepada lafazh "ahl al-kitâb", sedangkan 'athaf berfungsi menghubungkan antara dua kata atau dua kalimat yang berlainan. ${ }^{21}$

Meskipun jumhur ulama dikalangan Sunni membolehkan hukum menikahi wanita abl al-kitâb, namun dikalangan ulama pengikut mazhab terjadi dinamika pendapat yang tentu saja tidak sama dengan pendapat imam mereka. Menurut Hanafiyah (pengikut madzhab Hanafi), diharamkan menikahi wanita abl al-kitâb di darul harbi karena menimbulkan fitnah. ${ }^{22}$ Sedangkan menurut Malikiyah (pengikut madzhab Malik), mereka memiliki dua pendapat; Pertama, dimakruhkan menikahi wanita $a b l$ al-kitâb secara muthlak, baik drimmi mapun barbi. Kedua, dibolehkan secara muthlak, tidak dimakruhkan berdasarkan zahir nash. ${ }^{23}$

Pendapat yang lebih fariatif dikemukan oleh kelompok Syafi'iyah (pengikut madzhab Syafi'i). Dalam hal ini mereka mengklasifikasikan golongan ini

\footnotetext{
${ }^{21}$ Muhammad Ali Ash-Shabuni, Rawai'ul Bayan Tafsir Ayati Abkam min al-Qur'an, selanjutnya disebut Tafsir as-Shâbuni, (Jakarta: Dar al-Kitab al-Islamiyah, 2001), Juz.I, Cet. I, h. 225 dan bandingkan Wahbah alZuhaily, Op.Cit, h. 158

22 Abdur Rahman al-Jaziri, Kitab al-Figh 'Ala alMadzâabibi al- Arba'ah, (Beirut: Dâr al- Kutub al-'Ilmiah, 1990), Jld. IV, h. 73

23 Ibid, h. 73
}

menjadi dua kelompok; Pertama, Israiliah keturunan Ya'kub bin Ishaq bin Ibrahim, maka boleh menikahi wanita mereka secara muthlak. Kedua, selain Israiliah, terbagi kepada empat pendapat. Pendapat pertama, mengatakan jika masuk agama abl al-kitâb sebelum ada penyelewengan dan naskh, maka boleh menikahi wanita mereka.

Pendapat kedua, mengatakan jika masuk agama ini setelah terjadi perubahan, maka dilihat bila mereka tetap berpegang pada nilai yang hak dari kitab yang menyimpang itu hukumya dibolehkan menikahi wanita mereka. Pendapat ketiga, mengatakan jika masuk agama ini setelah penyelewengan dan naskh, seperti Yahudi dan Nasrani setelah diutusnya Nabi Muhammad Saw., maka tidak boleh (haram) menikahi wanita mereka. Dan pendapat keempat mengatakan jika terjadi keraguan padanya, seperti Nasrani Arab, maka tidak boleh menikahi wanita mereka. ${ }^{24}$

Demikian beberapa formulasi pendapat ulama sunni ketika memahami dalil yang terkait dengan hukum perkawinan muslim dengan wanita abl al-kitâb. Pada umumnya mereka sepakat membolehkan menikahi wanita abl al-kitâb, namun ada yang mengaitkan dengan kondisi-kondisi tertentu yang pada akhirnya perkawinan itu dilarang untuk dilakukan.

Berdasarkan permasalahan yang telah dipaparkan di atas terkait dengan perkawinan beda agama di Indonesia memunculkan pertanyaan; Pertama, bagaimana pengaturan beda agama di Indonesia?. Kedua, apakah agama selain Islam yang disahkan dan dianut oleh masyarakat Indonesia dapat disamakan dengan kelompok abl al-kitâb ataukah

24 Muhammad Asyarbini al-Khathib, Mughni Al-Mubtaj, (Mesir: Dâr al-Fikr, tt), Juz. III, h. 187 dan Bandingkan Mahmud Mathrohy, al-Majmu' Syarb alMubadždžab, (Beirut: Dâr al-Fikr, 1996, Jld. 17, h. 400 
tergolong musyrikat?. Ketiga, apakah hukum perkawinan beda agama yang terjadi di Indonesia dibolehkan (mubah) ataukah dilarang (haram)?. Ketiga pertanyaan ini menjadi masalah pokok dalam pembahasan disertasi ini dan masih dianggap aktual di jadikan sebagai objek penelitian.

Bertitik tolak dari latar belakang masalah sebagaimana yang telah diungkapkan di atas, maka permasalahan pokok yang menjadi kajian lebih lanjut dalam penelitian ini dapat dirumuskan dan sekaligus dibatasi sebagai berikut:

1. Bagaimana pandangan hukum Islam tentang kedudukan pluralisme agama dalam masyarakat Indonesia.

2. Bagaimana bentuk pengaturan tentang perkawinan beda agama di Indonesia.

3. Bagaimana pandangan hukum Islam terhadap perkawinan beda agama yang terjadi di Indonesia.

Penelitian ini mempunyai tujuan dan kegunaan secara akademik. Adapun yang menjadi tujuan penelitian ini adalah sebagai berikut:

1. Untuk mengetahui dan mendapatkan kejelasan secara utuh tentang kedudukan plurasime agama dalam masyarakat Indonesia.

2. Untuk mengetahui dan mendapatkan kejelasan secara utuh bagaimana bentuk pengaturan perkawinan beda agama di Indonesia.

3. Untuk mengetahui dan mendapatkan kejelasan secara utuh tentang pandangan hukum Islam terhadap perkawinan beda agama di Indonesia.

Sedangkan kegunaan dari Hasil penelitian ini secara khusus merupakan kelengkapan salah satu persyaratan untuk mengakhiri studi pada program Doktor (S3) dengan konsentrasi Hukum Islam (HI). Adapun secara umum kegunaannya adalah untuk menambah dan memperkaya khazanah ilmu keislaman di masa yang akan datang.

\section{Penjelasan Judul/Defenisi Operasional}

Indonesia disebut sebagai negara yang unik, karena memiliki beragam etnis, ras, agama dan budaya. Terkait dengan keberagaman agama dan kepercayaan yang dianut oleh masyarakat diakui oleh negara dengan hadirnya PP RI NO: I/PNPS/1965 dinyatakan bahwa agama yang dianut masyarakat Indonesia ada lima. Penganut kelima agama tersebut di dalam interaksi dan komunikasinya di tengah-tengah masyarakat sulit untuk menghindari munculnya benih cinta kasih di antara pemeluk agama yang berbeda itu dan berakhir dengan perkawinan.

Sebuah fakta yang tidak bisa dielakan dalam kehidupan masyarakat Indonesia sampai era sekarang adanya perkawinan beda agama (antara muslim dan non-muslim) terjadi ditengah-tengah masyakarat. Seiring dengan itu dalam menyikapi perkawinan beda agama yang terjadi masih memunculkan pendapat pro dan kontra dikalangan pakar-pakar hukum, khususnya pakar hukum Islam (ulama) di Indonesia, dan dapat dikatakan bahwa kasus perkawinan seperti ini dianggap perkawinan yang problematik.

Sehubungan perkawinan beda agama, maksudnya perkawinan yang terjadi antara muslim dan non muslim di Indonesia, secara normatif dan sosial masih menimbulkan perbedaan pendapat dan juga persoalanpersoalan hukum. Oleh karena itu, judul disertasi di atas bermaksud menemukan tentang pengaturan dan diskursus diseputar perkawinan antara muslim dan non muslim yang terjadi di Indonesia. Lebih lanjut kajian mendasar dan utama dalam pembahasan ini adalah melakukan peninjauan dan pengkajian secara utuh untuk menemukan rumusan hukum Islam tentang perkawinan beda agama (muslim dan non muslim) di Indonesia. Pada prinsipnya model perkawinan seperti ini telah dikenal dalam ajaran Islam yang bersumberkan kepada al-Qur`an dan Sunnah. Perkawinan 
beda agama atau keyakinan ini dalam Islam meskipun tidak dianjurkan, akan tetapi sesuatu hal yang dibolehkan dalam bentuk dispensasi bagi seorang muslim yang berkeinginan untuk melangsungkan perkawinan seperti ini.

\section{Metode Penelitian}

Penelitian ini bermaksud untuk mengungkap tentang kedudukan hukum perkawinan beda agama yang terjadi di Indonesia. Oleh karena itu kajian ini menitik beratkan kepada penelitian kepustakaan (library research), yaitu melakukan penela' ahan terhadap kitab perundang-undangan dan peraturanperaturan tentang perkawinan di Indonesia. Setelah data terkumpul, maka dalam pengolahannya penulis menggunakan metode berfikir Induktif, Deduktif, dan Komparatif (perbandingan).

Selanjutnya pada tahap melakukan peninjauan perkawinan beda agama di Indonesia menurut perspektif Alquran dan hadits, maka penulis melakukan penela'ahan terhadap kitab-kitab tafsir, kitab-kitab hadits dan diperkaya dengan kitab-kitab fiqh sebagai sumber primer. Sedangkan buku-buku keislaman lain yang ada relevansinnya dengan penelitian ini akan dijadikan sebagai sumber sekunder.

Untuk memperoleh pemahaman yang mendalam terkait dengan hukum Islam, maka penulis mempergunakan tiga pendekatan sebagai dasar analisis, antara lain:

1. Pendekatan Sosio-Historik. Penelitian ini berusaha memahami firman Allah yang diturunkan kepada Nabi Muhammad Saw dalam kondisi dan kultur bangsa Arab pada Abad VII Masehi. Sehubungan dengan itu informasi menyangkut komunitas Yahudi dan Nasrani (Abl al-kitâb) yang terdapat dalam kitab-kitab tarikh (sejarah) dan juga riwayat-riwayat lain merupakan bahan penting dalam memperkaya analisis. Dengan pendekatan ini penulis akan menelusuri latar belakang kehidupan komunitas tersebut sebelum kenabian dan di masa-masa turunnya wahyu. Dengan demikian akan dapat dipahami bagaimana karakteristik mereka ketika wahyu diturunkan kepada Nabi Muhammad Saw.

2. Pendekatan Content Analisis (analisis isi) terhadap ayat-ayat al-Qur`an, terutama dengan mengetahui aspek nu₹ul dan aspek asbabun nuzul ayat. Ilmu tafsir adalah sarana yang disediakan dalam khazanah ilmu-ilmu keislaman untuk memahami kandungan alQur`an. Di antara ilmu tafsir yang relevan dengan tulisan ini adalah Makiyah dan Madaniyah, Munasabah dan kaedah-kaedah kebahasaan, seperti ' $A m$ dan Khash, Nasikh dan Mansukh, Mutblak dan Muqayad, dsb. ${ }^{25}$ Langkahlangkah memahami, meneliti dan menguraikan tema tertentu ditempuh metode tematik (al-mawdhu'i) ${ }^{26}$ dengan cara-cara sebagai berikut: Pertama, menghimpun ayat-ayat al-Qur'an yang relevan dengan tema di atas. Kedua, menyusun ayat-ayat tersebut secara kronologis (Asbabun Nuzul) dan sistematis menurut tujuan. Ketiga, menguraikan ayat demi ayat dan penjelasannya dengan menggunakan ilmu bantu yang relevan. Keempat, merumuskan dan membahas masalah yang diteliti.

3. Pendekatan fiqh (Normative Legalistic Approach), dengan berpijak kepada filsafat hukum. Judul di atas menghendaki pemikiran legalistic, sebab

${ }^{25}$ Lebih lanjut lihat Manna' al-Qattan, Mabâhis fi 'Ulûm al-Qur'an, (Riyad: Mansyurah al-'Asr al-Hadîts, 1973), h. 97

${ }^{26}$ Abd al-Hayy al-Farmawi, al-Bidayah fi Tafsir al-Maudhû'i, (Qahirah: al-Hadharah al-Arabiyyah, 1977), h. 52 
masalah perkawinan beda agama di Indonesia sarat dengan aspek hukum, sebab perkawinan ini akan menghadapi berbagai permasalahan hukum, seperti nasab anak, nafkah, perceraian dan kewarisan. Sehubungan dengan itu maka perkawinan beda agama perlu di tetapkan hukumnya, baik menurut negara maupun agama.

Dalam tahapan menetapkan hukum, penulis akan menggunakan metode istinbath yang telah dirumuskan oleh AlDawalibi, ${ }^{27}$ yaitu metode bayani, metode ta'lili (qiyasi), dan metode istishlabi.

Demikianlah metode penelitian yang penulis persiapkan dan gunakan dalam upaya penelusuran dan pemecahan masalah terhadap judul disertasi di atas. Dan menurut hemat penulis dengan menggunakan metode seperti yang dijelaskan di atas telah memadai untuk menemukan jawaban dari permasalahan di atas.

\section{Cakupan makna ahl al-kitâb}

Cakupan makna ahl al-kitâb itu tidak tertuju kepada komunitas Yahudi dan Nasrani saja akan tetapi juga berlaku kepada agama-agama selainnya yang mempunyai kitab suci. Pendapat penulis ini berdasarkan beberapa pertimbangan, antara lain:

Pertama, Seperti terungkap dalam pembahasan terdahulu, bahwa term abl alkitâb itu suatu pengistilahan dalam alQur’an yang ditujukan kepada kelompok pemeluk agama yang memiliki kitab suci yang diwahyukan Allah kepada Nabi dan Rasul-Nya. Dalam hal ini yang perlu dipahami dan dipertimbangkan bahwa ungkapan yang menunjuk kepada

${ }^{27}$ Ma'rûf al-Dawalibi, al-Madkhâl fi Tlmi Ushûl al-Figh, (Beirut: Dar al-Kitab al-Jadid, 1965), h. 422 pengertian itu bervariasi, seperti ûtu alkitâb, ataina bum al-kitâb, yaqra'una al-kitâb, dan yaqra'una nashiban min al-kitâb. Meskipun term abl al-kitâb dalam al-Qur'an tertuju kepada Yahudi dan Nasrani, akan tetapi ketika al-Qur'an menggunakan term ataina bum al-kitâb, maka di antara pengertiannya berlaku secara umum kepada seluruh kelompok pemeluk agama yang dibawa oleh nabi dan rasul terdahulu, seperti firman Allah dalam Q.S. al-An'am: 89:

Mereka Itulah orang-orang yang telah Kami berikan Kitab, hikmat dan kenabian jika orang-orang (Quraisy) itu mengingkarinya, Maka Sesunggubnya Kami akan menyerabkannya kepada kaum yang sekalikali tidak akan mengingkarinya.

Untuk memahami ayat di atas dapat merujuk ke dalam salah satu kitab tafsir Jami ul Bayan, sebuah karya tafsir klasik dan kitab tafsir yang belum terkontaminasi dengan mazhab-mazhab. Dalam kitab itu dijelaskan pengertian ayat di atas sebagai berikut:

Penafsiran dari penggalan ayat (mereka yang telah diberikan kepadanya kitab, bukum dan kenabian), menurut Abu Ja'far: maksud dari kata "mereka", yakni merekamereka yang dinamakan dan berkedudukan sebagai nabi dan rasul Allah SWT mulai dari Nub dan keturunannya yang mana semuanya mereka itu telah mendapat petunjuk melalui agama Islam dan sekaligus mereka telah dipilib untuk menyampaikan risalab kepada hamban-Nya. Sedangkan mereka "orang-orang yang diberikan kitab" pengertiannya adalah mereka yang mendapatkan shubuf Ibrabim dan Musa, kitab Zabur kepada Nabi Daud, dan kitab Injil kepada Nabi Isa as. semoga Allah 


\section{melimpahkan keselamatan kepada mereka semua. ${ }^{28}$}

Dalam ayat itu terkandung maksud adanya sejumlah nabi dan rasul sebagaimana yang disebutkan dalam ayat-ayat sebelumnya, mereka semua diberikan kitab suci oleh Allah SWT. Selanjutnya penjelasan yang senada dengan redaksi yang berbeda tentang ayat di atas juga dikemukakan oleh Isma`il Haqy dalam kitabnya tentang maksud dari ayat di atas sebagai berikut: ${ }^{29}$

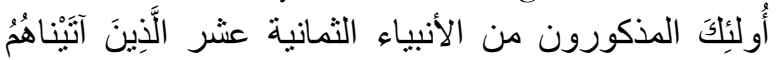

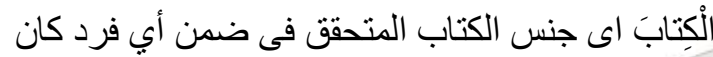

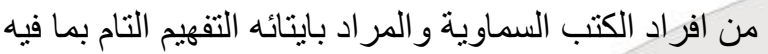

من الحقائق و التمكين من الإحاطة بالجلائل و الدقائق ...

Mereka yang disebutkan itu sebagian para nabi berjumlah 18 orang yang telah diberikan kitab suci oleh Allah kepada mereka, artinya jenis kitab-kitab yang dikategorikan ke dalam kitab-kitab samawi. Sedangkan yang dimaksud dengan kata "Ita'ibi" dalam ayat berupa pemahaman yang sempurna tentang kandungannya, antara lain; hakekatbakekat dan kemungkinan yang meliputi keagungan dan kehalusan / ketelitian....

Begitu pula dengan term Ûtu al-kitâb dalam beberapa ayat menunjuk secara umum kepada umat-umat terdahulu yang diberikan kitab suci kepada mereka, seperti terungkap dalam firman Allah dalam Q.S. al-Nisa': 131

Dan kepunyaan Allab-lab apa yang di langit dan yang di bumi, dan sungguh Kami telah memerintabkan kepada orang-orang yang diberi kitab sebelum kamu dan (juga) kepada kamu; bertakwalah kepada Allah. tetapi jika kamu kafir Maka (ketabuilab),

${ }^{28}$ Muhammad Ibn Jarir ibn Yazid ibn Katsir ibn Ghalib al-Amaly Abu Ja'far al-Thabary, Op.Cit, Juz. II, h. 514

${ }^{29}$ Isma'il Haqy ibn Musthafa al-Istanbuly alHanafi al-Khaluti, Rûh al-Ma'ani, (Beirut: Dâr al-Fikr, tt.), Juz. III, h. 62
Sesungguhnya apa yang di langit dan apa yang di bumi hanyalah kepunyaan Allab[360] dan Allah Maba Kaya dan Maha Terpuji.

Ayat ini memaparkan, bahwa penggunaan term ûtu al-kitâb berlaku secara umum terhadap agama-agama yang memiliki kitab suci yang diturunkan Allah sebelum kerasulan Muhammad SAW. Hal ini dapat dipahami dari penafsiran ayat yang dikemukakan oleh Isma'il al-Haqy sebagai berikut: ${ }^{30}$

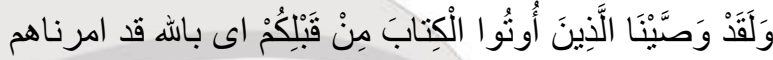

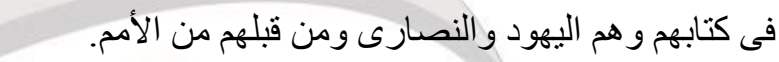
و اللام فى الكتاب للجنس يتناول الكتب السماوية ومن ونائن متعلقة بوصينا او بأوتوا وَاِِيَّاكُمْ عطف على على الذين الى الى وصيناكم يا امة محمد فى كتابكم أَنِ انَقُو اللَّ

Dan Kami perintabkan orang-orang yang telah diberikan kitab kepada mereka dari sebelum kamu, artinya demi Allab sungguh Kami perintah mereka melalui kitab mereka, yaitu Yabudi, Nasrani, dan umat-umat lain sebelum mereka. Hurf "lam" pada kata alkitâb memfaedabkan bagi jenis yang mencakup kitab-kitab samawi dan orangorang yang terkait dengan perintab Kami atau diberikan kepada mereka al-kitâb dan juga kepada kamu agar bertaqwa kepada Allah.

Senada dengan pendapat di atas juga dikemukakan oleh al-Qurthubi ketika menafsirkan ayat itu ia mengatakan: ${ }^{31}$

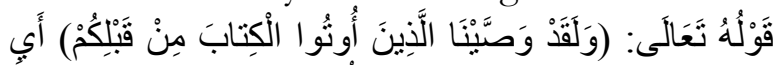

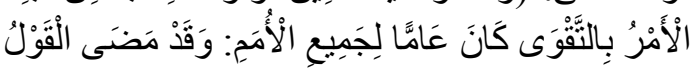

30 Isma il Haqy ibn Musthafa al-Istanbuly alHanafi al-Khaluti, Op.Cit, Juz. III, h. 62

31 Abu Abdullah Muhammad ibn Ahmad ibn Abi Bakar ibn Farh al-Anshari al-Khazraji Syamsuddin al-Qurthubi, al-Jâmi' li Abkam al-Qur'an, populer disebut Tafsir al-Qurthubi, (Kairo: Dar al-kitâb Al-Mishriyah, 1384 H / 1964 M), Juz. V, Cet. II, h. 408 


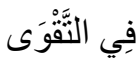

Firman Allab SWT.: (Dan sesunggubnya Kami telah perintabkan orang-orang yang diberikan kepada mereka al-kitâb sebelum kamu), artinya perintah untuk bertaqwa, dan itu berlaku kepada sekalian umat-umat: dan telab berlalu penjelasan tentang taqwa.

Melihat konteks ayat ini, agaknya term ûtu al-kitâb yang terdapat dalam ayat tersebut bersifat umum bagi umat-umat terdahulu yang diberikan kitab suci. Karena perintah bertaqwa dalam ayat tersebut juga bersifat umum bagi semua umat.

Kedua, al-Qur'an ketika menginformasikan tentang nabi dan rasul yang diutus oleh Allah ke permukaan bumi ini, bukan hanya untuk etnis Bani Isra il saja, akan tetapi semua etnis sebelum kerasulan Muhammad SAW. selalu diturunkan kepada mereka seorang pemberi peringatan atau nabi dan rasul. Hal ini seperti terungkap dalam firmannya dalam Q.S. an-Nisa': 164:

Dan (kami telah mengutus) Rasul-rasul yang sungguh telah Kami kisabkan tentang mereka kepadamu dabulu, dan Rasul-rasul yang tidak. Kami kisabkan tentang mereka kepadamu. dan Allah telah berbicara kepada Musa dengan langsung.

Ayat ini menjelaskan bahwa rasulrasul utusan Allah itu sebagiannya telah dikisahkan tentang mereka, dan sebagian yang lain belum lagi dikisahkan tentang keberadaan mereka. Untuk lebih kongkritnya penjelasan ayat ini terkait dengan jumlah nabi dan rasul telah dikemukakan oleh seorang pakar tafsir klasik bernama Ibn Katsir dalam kitabnya sebagai berikut: ${ }^{32}$

32 Abu al-Fida ' Isma'il ibn Umar ibn Katsir alQarsy al-Bashri, Tafir al-Qur'an al-'Azhim, populer disebut Tafsir Ibn Katsir, (Beirut: Dar Thaibah li an-Nasy wa al-Tauzi', 1420 H/ 1999 M), Cet. II, Juz. II, h. 470
Dan firman-Nya: (dan rasul-rasul sungguh telah Kami kisabkan kepadamu terdabulu...), artinya sebelum ayat ini, yakni: pada surat-surat makiyah dan selainnya. Inilah nama-nama para nabi yang dijelaskan dalam al-Qur'an, seperti Adam, Idris, Nuh, Hud, Shalih, Ibrahim, Luth, Isma'il, Ishaq, Ya'qub, Yusuf, Ayub, Syu'ab, Musa, Harun, Yunus, Daud, Sulaiman, Ilyas, alYasa', Zakariya, Yabya, 'Isa,(keselamatan untuk mereka semua), begitu pula Zul Kifli menurut mayoritas abli tafsir, dan penghulu semuanya Mubammad $S A W$.

Dan selanjutnya dikemukakan pula para nabi dan rasul yang tidak dikisahkan mereka itu dalam al-Qur'an dan ini cukup banyak jumlah mereka, sebagaimana dipaparkan oleh Ibn Katsir sebagai berikut: ${ }^{33}$

Informasi yang sama dengan redaksi yang berbeda dengan ayat di atas yang menjelaskan bahwa semua umat-umat terdahulu dari berbagai suku bangsa dan budaya yang berbeda-beda, kepada mereka itu Allah telah utus para nabi dan rasul yang bertugas membimibng serta memberi peringatan, dapat pula ditemukan dalam Q.S. al-Ghafir ayat 78. Secara umum ayat ini memaparkan bahwa Allah SWT telah mengutus beberapa orang nabi dan rasul sebelum Muhammad SAW. dan mereka itu ada dikisahkan kepada Nabi SAW. dan ada pula yang tidak dikisahkan kepadanya. Dan selanjutnya hal yang sama dapat pula dijumpai dalam Q.S. Fathir ayat 24. Ayat ini menjelaskan bahwa masing-masing umat pada dasarnya telah ada diutus oleh Allah sebagai pemberi peringatan.

Ketiga, penyebutan beberapa agama, seperti Yahudi, Nasrani, Majusi, dan Shabi'un dalam al-Qur'an menurut penulis tidak serta merta menafikan agama-agama

${ }^{33} \mathrm{Ibid}$ 
yang tidak disebutkan dalam al-Qur'an yang jumlahnya justru jauh lebih banyak dibanding yang disebutkan. Dalam hal ini penulis sependapat dengan argumen yang dibangun oleh Muhammad Rasyid Ridha sebagi penguat pendapatnya yang menyatakan bahwa semua agama yang punya kitab suci itu dapat digolongkan kepada abl al-kitâb. Pernyataan itu dapat dikemukakan sebagai berikut: ${ }^{34}$

Dan secara kongkrit (zhabir) al-Qur'an menyebutkan sebagian penganut agama terdabulu, seperti Sbabi in dan Majusi, dan tidak menyebutkan agama Hindu dan agama Budha begitu pula dengan agama Kong $\mathrm{Hu}$ Cu (Konfusius); disebabkan bahwa agama Shabi in dan Majusi itu telah populer di kalangan orang Arab yang nota benenya komunitas pertama sebagai lawan dialog alQur'an ketika itu. Di samping itu juga kedua kelompok tersebut tempat tinggalnya berdekatan dengan orang Arab, yakni di wilayah Irak dan Bahren. Dan mereka tidak pernah bepergian ke wilayah India, Jepang, dan Cina yang kalau mereka pergi ke sana tentu mereka akan mengetabui ada komunitas agama lain di sana. Yang dimaksud dari ayat itu hanya mencukupkan menyebutkan agama-agama yang populer saja di kalangan mereka (orang Arab). Oleh karena itu tidak ada gunanya menyebutkan kepada mereka agama-agama yang asing dan tidak mereka ketabui ketika turun wabyu, dan sekaligus tidak berarti menyembunyikan atas lawan dialog setelah itu, karena sesunggubnya Allah SWT. juga akan menerangkan bagaimana keberadaan agama Hindu. Budha dan selain mereka.

Keempat, dan dimaklumi, bahwa alQur’an menjelaskan dengan tegas tentang penerimaan jizyah (pajak diri) dari kelompok

34 Muhammad Rasyid Ridha, Tafsir al-Qur'an al-Hakîm, populer disebut tafsir al-Manâr, (Kairo: al-Hay'ah al-Mishriyah al-'Ammah li al-kitâb, 1990), Juz. VI, h. 156 abl al-kitâb, ${ }^{35}$ dan tidak disebutkan tentang jizyah itu dipungut/ditagih dari selain mereka. Namun demikian, berpedoman kepada praktek dari Nabi SAW. dan para khalifah (al-Khulafa') tidak menerimanya dari musyrik Arab, dan menerimanya dari kelompok Majusi di daerah Bahren, Hajara, dan Persia. ${ }^{36}$ Berpedoman kepada sunnah fi'liyah itu tentu saja dapat dipahami, bahwa Majusi termasuk kelompok abl al-kitâb, karena dari mereka dipungut jizyah, meskipun secara langsung mereka tidak disebut dengan panggilan abl al-kitâb.

Kelima, sebagaimana dipahami bahwa ciri khusus abl al-kitâb adalah adanya seorang nabi atau rasul membawa wahyu dari Allah SWT. Secara kongkrit agama yang disebut nabinya adalah Musa dan Isa as. di kalangan Bani Isra il, lalu pertanyaannya adalah bagaimana dengan agama-agama selain keduanya, seperti Shabi un dan Majusi. Dalam hal ini, Abi Manshur Abd al-Qahir ibn Thahir alBaghdadi (w. 429 H) memaparkan dalam kitabnya, ${ }^{37}$ " sesungguhnya orang-orang Majusi mengakui adanya seorang nabi bagi mereka bernama Zaruaster yang menurut mereka ia telah menerima wahyu dari Allah SWT. Begitu pula penganut agama Shabi un, mereka juga menda'wakan akan adanya seorang Nabi bagi mereka yang bernama (Harmas) dan (Walis), selanjutnya

35 Lihat. Q.S. al-Taubah: 29.

36 Peritiwa ini terdapat dalam kitab shahih Bukhari dan Muslim dan selain kedunya dari kitab-kitab hadits. Ditemukan dalam riwayat Ahmad, Bukhari, Abu Daud, Turmizi, dan selain mereka tentang hadits yang bersumber dari Abdurrahman ibn 'Auf; yakni Nabi Muhammad SAW. memungut jizyah (pajak) dari kelompok Majusi Hajara. Begitu pula Umar ibn alKhaththab juga melakukan hal yang sama. (Muhammad Rasyid Ridha, Op.Cit, Juz. VI, h. 156 ).

37 Abu Mansur Abdul Qahir ibn Thahir ibn Muhammad ibn Abdullah al-Baghdadi, al-Farq Baina alFiraq wa Bayan al-Furqah al-Najiyah, (Beirut: Dar al-Afaq al-jadidah, 1977), Cet. II, Juz. I, h. dan juga dikutip oleh Muhammad Rasyid Ridha, Op.Cit, h. 154 
dianggap nabi para failosof Yunani, seperti (Heraklius) dan (Plato), dan sekalian tokohtokoh syari'at masing-masing mereka mengklaim bahwa kepada mereka telah diturunkan wahyu dari langit melalui nabi mereka. Menurut pendapat mereka, wahyu itu isinya meliputi perintah, larangan, perkhabaran dari resiko kematian, pahala, siksaan, syurga dan neraka sebagai balasan bagi orang- orang yang beramal.

Begitu pula dengan agama Budha, sebenarnya Budha itu adalah seorang nabi. Hal ini terungkap dalam kitab tafsir karya imam al-Qashimi (w. 1332 H/ 1914 M) ketika menafsirkan surat al-Tîn tersebut di dalamnya dinyatakan sebagai berikut:

Dan menjelaskan sebagian pakar dimasanya memahami firman Allah SWT. "وَالثّنينِ", yakni sebagai pohon di mana pendiri agama Budha memperoleh wahyu-wabyu Ilahi yang secara hakekat telah banyak terjadi perubaban dari asalnya, karena ajaranajaran Budha tidak tercatat di zamannya, dan hanya berdasarkan riwayat sama balnya dengan hadits-hadits yang diriwayatkan dengan lisan/mulut. Lalu setelah itu baru dituliskan ketika pengikutnya telab maju. Kemudian imam al-Qashimi menegaskan: "Dan yang lebih kuat menurut pandangan kami babkan yang pasti, bila tafsir kami ini benar adalab babwa dia (Budha) adalah seorang nabi yang benar". 38

Demikialah beberapa dalil dan argumentasi yang dapat penulis sajikan dalam pembahasan ini, khusus yang berhubungan dengan cakupan makna dari / ûtu al-kitâb dalam perspektif al-Qur'an. Berdasarkan keterangan di atas menurut hemat penulis sangat beralasan kiranya dikatakan bahwa ungkapan abl al-kitâb

38 Muhammad Jamaluddin ibn Muhammad Sa'id ibn Qashim al-Halaq al-Qashimi, Mahâsin al-Ta 'wîl, (Beirut: Dâr al-kitâb al- 'Ilmiyah, 1418 H), Cet. I, Juz. IX, h. 502 dalam al-Qur`an itu pengertiannya bukan saja tertuju kepada komunitas penganut agama Yahudi dan Nasrani dari keturunan Bani Isa'il saja, akan tetapi dapat diberlakukan kepada komunitas dan etnis lain yang menganut kedua agama itu atau menganut agama- agama lain yang memang mereka dalam menjalankan agamanya berpedoman dan sekaligus membaca kepada kitab suci atau menyerupai kitab suci. Disebut menyerupai kitab suci dikarenakan kitab tersebut dipertanyakan orisinalitasnya dari Tuhan dan juga karena tidak disebut secara jelas dalam al-Qur'an nama kitab tersebut sebagaimana kitabnya Yahudi dan Nasrani.

\section{A. Kedudukan Agama-Agama Yang Berkembang di Indonesia}

Agama-agama yang berkembang dan di anut penduduk Indonesia, seperti Kristen Katolik dan Protestan, Hindu, Budha, dan Konghucu dapat diposisikan ke dalam kelompok abl al-kitâb dengan beberapa pertimbangan sebagai berikut:

1. Secara historis, kemunculan dan awal perkembangan agama- agama tersebut diperkenalkan dan dibawa oleh tokohtokoh yang memiliki keutamaan dibanding masyarakat umum di masanya, yang disebut dengan nabi atau reformis. Semua mereka itu mengajarkan kepada umat atau pengikutnya ajaran/paham monoteisme, yaitu suatu keyakinan kepada Tuhan Yang Maha Esa (Tahuid), meskipun dengan menggunakan simbul yang berbedabeda.

2. Secara doktriner, ayat-ayat yang menginformasikan tentang abl al-kitâb itu sangat variatif, baik dari segi pengistilahan yang dijumpai dalam ayat-ayat al-Qur'an maupun dari segi cakupan makna yang dituju oleh ayat- 
ayat tersebut. Secara umum memang menunjukkan kepada kelompok Yahudi dan Nasrani, akan tetapi penggunaan istilah itu berlaku kepada seluruh penganut agama-agama. Dan dalam hal ini memasukkan agamaagama yang ada di Indonesia ke dalam kelompok abl al-kitâb merupakan sesuatu yang beralasan dan berdalil.

3. Secara simbolis, setelah melakukan penela'ahan terhadap ayat- ayat alQur'an didapatkan suatu petunjuk nyata, bahwa abl al-kitâb itu bila ditinjau dari aspek etimologi dan terminologi disimbulkan dengan "kitab suci". Karena itu setiap keyakinan atau agama yang tidak memiliki kitab suci dalam menjalankan keyakinannya, maka tidak dapat dikatakan abl al-kitâb melainkan musyrikat. Adapun agama-agama yang ada di Indonesia semuanya memiliki kitab suci, seperti Kristen kitab sucinya Injil, Hindu kitab suci Tripitaka, Budha kitab sucinya Weda/Veda, dan Konghucu kitab sucinya Lung Yu.

4. Secara orisinalitas, mencermati bagaimana keberadaan komunitas yang secara langsung ditunjuk oleh ayat, yaitu umat Yahudi dan Nasrani ternyata ketika masa turun wahyu ajaran agama mereka tidak orisinal lagi seperti ajaran semula. Begitu pula dengan agama-agama yang berkembang di Indonesia ajaran kitab-kitabnya juga tidak orisinal. Dengan demikian menilai suatu agama dari aspek orisinalitas ajarannya untuk menentukan abl alkitâb atau tidaknya tentu ini pendapat tidak berlasan dan tidak dapat dibenarkan.

Demikian beberapa alasan dan argumentasi yang dapat penulis tampilkan sebagai penguat pendapat penulis yang menyatakan bahwa agama-agama yang berkembang di Indonesia dapat dikelompokkan ke dalam pengertian abl alkitâb.

\section{Hukum Perkawinan Beda Agama di Indonesia}

\section{(a) Perakawinan Laki-laki Muslim dengan Wanita non Muslim}

Dalam pembahasan terdahulu telah disebutkan, bahwa agama yang berkembang di negara Indonesia ini dapat dikelompokkan ke dalam pengertian abl alkitâb, bukan ke dalam kelompok musyrikat. Penetapan ini tentu saja setelah melakukan penelitian yang mendalam terhadap nashnash yang ada menginformasikan tentang mereka dan juga selain mereka. Setelah dicermati pendapat para ulama, ternyata mayoritas ulama memahami bahwa term $a b l$ al-kitâb itu tidak semata ditujukan kepada Yahudi dan Nasrani, tetapi juga diberlakukan kepada kelompok lain yang memiliki kitab suci dalam agamanya, tanpa mempertimbangkan apakah kitab itu masih orisinal ataukah sudah terkontaminasi dengan ajaran-ajaran takhayul dan khurafat.

Sebagai landasan hukum untuk menetapkan hukum perkawinan beda agama di Indonesia antara seorang muslim dengan non muslim dapat merujuk kepada firman Allah dalam Q.S. al-Maidah ayat 5. Ayat ini secara jelas dan tegas menggunakan kata (أحل لكم) yang berarti dihalalkan atau dibolehkan bagimu memakan sembelihan abl al-kitâb dan juga dihalalkan bagimu menikahi wanita baik-baik dari kalangan mereka. Meskipun ayat ini secara tekstual sudah tegas membolehkan, namun beberapa persoalan masih menimbulkan pro dan kontra di kalangan sahabat dan para ulama, seperti siapa itu abl al-kitâb dan kedudukan ayat ini apakah masih tetap (mubkam) ataukah sudah 
dihapuskan/dibatalkan hukumnya (dinasakbkan).

Sahabat Nabi SAW. bernama Umar ibn Khaththab tidak senang dengan perkawinan Huzaifah yang beristrikan seorang wanita Yahudi. Ia mengirim surat kepada Huzaifah agar wanita itu diceraikan. Setelah itu ditanyakan apakah engkau mengharamkan perkawinan ini?, jawabnya tidak, hanya aku khawatir engkau mengawini perempuan pelacur dari kalangan mereka. ${ }^{39}$ Pendapat Umar ini menunjukkan kehati-hatian dan kekhawatirannya kepada kelompok tersebut, dan bukan menunjukkan bahwa perkawinan dengan wanita kitabiyah/abl al-kitâb itu hukumnya haram. Kalau dapat dikatakan pendapat Umar ini lebih bersifat politis, dan kalau ingin menikah juga dengan kelompok mereka harus selektif.

Pendapat yang lebih tegas lagi dikemukakan oleh putra beliau bernama Abdullah ibn Umar, ia memposisikan abl alkitâb itu sama dengan musyrik, dan konsekwensinya tentu saja ia mengharamkan seorang muslim menikah dengan wanita abl al-kitâb (non muslim). Pendapat ini terungkap dari sebuah riwayat sebagai berikut:

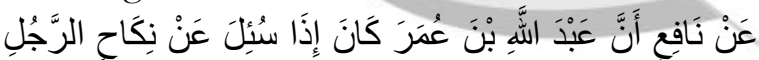

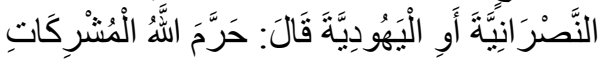

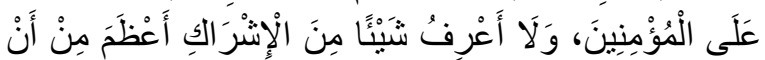

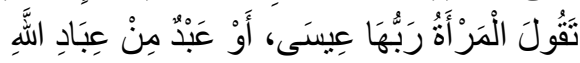
Dari Nafi bahwa Abdullah ibn Umar pernah ditanya dari seorang laki-laki muslim yang menikah dengan wanita Nashrani dan Yabudi, lalu ia menjawab: Allah telah mengharamkan wanita-wanita musyrikah atas orang beriman, dan aku tidak mengetabui kemusyrikan yang lebih besar dari

39 Abu 'Abdillah Muhammad ibn Ahmad ibn Abi Bakar ibn Farh al-Anshari al-Khazraji Syamsuddin al-Qurthubi, Op.Cit, h. 68 keyakinan seorang perempuan yang berkata tuhannya adalah Isa atau salab seorang dari hamba Allab". ${ }^{40}$

Pendapat ini diikuti oleh beberapa ulama di kalangan Syi'ah Imamiah dan sebahagian dari Syi'ah Zaidiyah. Di samping mereka mengikuti pendapat Ibn Umar juga mereka memperkuat pendapatnya itu dengan mengatakan bahwa surat al-Maidah ayat 5 ini telah dinasakh (dibatalkan hukumnya) oleh surat alBaqarah ayat 221 dalam bentuk naskbul khash bil Am (dalil yang umum menasakh dalil yang khusus). ${ }^{41}$

Pendapat ini tidak sejalan dan bahkan kontradiktif dengan mayoritas pendapat sahabat Nabi SAW., seperti Ibn Abbas, Usman ibn Affan, Thalhah, dan Huzaifah. Begitu pula diperkuat dengan pendapat tabi' in, seperti Sa'id ibn Musayyab, Sa'id ibn Juber, Hasan, Mujahid, Thaus, 'Ikrimah, al-Syu'bi, Dhaha' dan para fuqaha`. Mereka tidak setuju kalau dikatakan bahwa surat al-Baqarah ayat 221 itu menasikh surat al-Maidah ayat 5 , sebab surat al-Baqarah lebih dahulu diturunkan di kota Madinah. Sedangkan surat al-Maidah ayat 5 diturunkan terakhir juga di kota Madinah. Seharusnya yang menasakh itu yang terakhir turun bukan yang pertama. ${ }^{42}$

Dengan demikian dapat dikatakan pendapat Ibn Umar yang mengharamkan menikahi wanita abl al-kitâb bertolak belakang dengan pendapat shahabat dan tabi'in, serta praktek yang dilakukan oleh sahahat Nabi SAW., seperti Usman ibn Affan yang menikah dengan Nailah ibnti Quraqashah al-Kalbiyah beragama Nasrani, Thalhah ibn Ubaidillah dengan perempuan

\footnotetext{
40 Ibid

${ }^{41}$ Muhammad Ali al-Shabuni, Op.Cit, h. 225

42 Abu 'Abdillah Muhammad ibn Ahmad ibn
} Abi Bakar ibn Farh al-Anshari al-Khazraji Syamsuddin al-Qurthubi, Op.Cit, h. 68 
Yahudi di Damaskus, Huzaifah menikah dengan wanita Yahudi di Madinah. Begitu pula dengan mayoritas tokoh-tokoh tabi' in yang populer juga membolehkan perkawinan dengan abl al-kitâb. ${ }^{43}$

Imam al-Qurthubi (w. $671 \mathrm{H}$ ) pernah mengkritisi pendapat Ibn Umar di atas, katanya hadits Ibn Umar itu tidak dapat dijadikan hujjah, sebab Ibn Umar termasuk sosok laki-laki yang tidak tegas menentukan sikap dalam mempergunakan dalil (للأن ابن عمر رحمه الله كان رجلا متوقفا). Ketika ia mendengar dua ayat, satu ayat menghalalkan dan ayat lain mengharamkan, ia tidak menggunakan metode nasakh melainkan ia langsung saja menta 'wilkannya. ${ }^{44}$

Selanjutnya, dalam satu riwayat disebutkan bahwa Ibn Abbas pernah memberikan pembatasannya dengan mengatakan, bahwa abl al-kitâb itu adalah Yahudi dan Nasrani, dan kebolehan menikah dengan wanita mereka, hanyalah mereka yang berada di wilayah perlindungan pemerintahan Islam dan bukan yang tinggal di luar pemerintahan Islam atau dalam wilayah permusuhan. ${ }^{45}$ Pendapat ini tidak disetujui oleh mayoritas ulama, sebab tidak ada di kalangan ulama yang mengharamkan perkawinan tersebut meskipun di wilayah perang, karena ayat al-Qur'an membolehkan perkawinan tersebut secara umum.

43 Abu al-A'la al-Maududi, Op.Cit, h. 112, lihat juga al-Sayyid Sabiq, Fiqh al-Sunnah, (Beirut: Dâr al-kitâb al-Arabi, 1977), Jld. II, h. 101

${ }^{44}$ Abu 'Abdillah Muhammad ibn Ahmad ibn Abi Bakar ibn Farh al-Anshari al-Khazraji Syamsuddin al-Qurthubi, Op.Cit, h. 68

45 Abu Su'ud al-Ma'adi Muhammad ibn Muhammad ibn Mushtafa, Irsyad al-'Aqli Salim ila Mazaya al-kitâb al-Karim, (Beirut: Dar Ihya' al-Turas al'Arabi, tt), Juz. III, h. 9 dan bandingkan Abu 'Abdillah Muhammad ibn Ahmad ibn Abi Bakar ibn Farh alAnshari al-Khazraji Syamsuddin al-Qurthubi, Op.Cit, Juz. VI, h. 79
Berdasarkan penjelasan di atas, maka menurut penulis pendapat yang mengharamkan perkawinan dengan abl alkitâb tidak punya alasan yang kuat, di samping tidak sejalan dengan nash alQur`an juga menyalahi mayoritas pendapat dan praktek para sahabat Nabi SAW, begitu pula pendapat para tabi'in.

Alasan utama yang dijadikan dalil adalah mereka telah musyrik, dan orang musyrik dilarang menikahi mereka baik lakilaki maupun perempuan. Kalau dikatakan mereka (abl al-kitâb) itu telah melakukan kemusyrikan memang sesuatu yang tidak bisa dibantah, sebab mereka dalam keyakinannya telah mengatakan Isa dan Uzair anak Allah, namun tidak serta merta mereka dapat divonis menjadi musyrik. Salah satu indikator untuk mendukung pernyataan di atas adalah ayat-ayat yang menginformasikan tentang mereka (abl alkitâb/ûtu al-kitâb) tetap dibedakan dengan informasi orang-orang musyrik.

Dalam hal ini penulis sependapat dengan alur pemikiran Imam Thaba'thaba'i berkenaan dengan musyrik itu. Menurut beliau kata "al-musyrikatun" adalah isim fa el (sabjek/pelaku) yang berasal dari kata "alisyrak" yang pengertiannya adalah menjadikan Allah bersekutu. Dan perlu diketahui bahwa perbuatan ini mempunyai tingkatan-tingkatan yang satu sama lainnya berbeda dari segi al-zubur (nyata) dan alkhuffa' (tidak nyata), sama halnya kata kafir dan iman. ${ }^{46}$

Jika ada suatu kepercayaan yang mempercayai banyak Tuhan atau menjadikan berhala sebagai Tuhan, hal ini merupakan syirik nyata (al-Zubr) dan ia menjadi tidak nyata (al-kbuffa') apa yang dipraktekkan oleh abl al-kitâb yang

46 Muhammad Husein Thabathaba i, al-Mîzân fi Tafsir al-Qur'an, ( Beirut: Mu`assasah al-A'la li alMathbu'ah, 1411 H/1991 M), Juz. V, h. 206 
mengingkari kenabian Muhammad SAW., terutama perkatan mereka: "Uqair anak Tuban atau al-Masib anak Tuban ..." perkataan ini termasuk syirik, namun masih samar, karena apa yang mereka ucapkan itu tidak terlepas dari sebab-sebab meskipun itu termasuk perbuatan syirik, namun tidak menjadikan ia bersifat syirik dan berubah status menjadi musyrik. Hal seperti ini sama halnya dengan orang Islam yang meninggalkan kewajiban-kewajiban agama, ia telah melakukan kekafiran tetapi ia tidak disebut orang kafir. ${ }^{47}$

Selanjtunya, penulis juga sepaham dan sependapat dengan pandangan seorang tokoh Islam yang fenomenal, yakni Ibn Taimiyah (w. 728 H). Menurutnya term abl al-kitâb itu tidak termasuk ke dalam cakupan makna "masyrikun". Menurut beliau, Allah SWT. sendiri dalam firman-Nya membedakan kedua kelompok ini, seperti terungkap dalam Q.S. al-Hajji ayat 17.

Suatu hal yang memang tidak dapat dibantah, bahwa mereka telah terjebak dengan sifat syirik dan melakukan hal-hal yang berbau kesyirikan, sesuai dengan penjelasan Allah SWT. dalam surat alTaubah ayat 31 .

Menurutnya, abl al-kitâb itu asal (pokok) ajaran agama mereka tidaklah syirik, karena Allah telah mengutus para rasul membawa misi tauhid. Setiap orang yang beriman kepada rasul-rasul dan kitabkitab yang diturunkan tidaklah asal agamanya syirik, namun demikian pengikut Nashrani telah mengada-adakan sesuatu yang berbau syirik (baca Q.S. Yunus/10: 18), menetapkan bahwa mereka telah terjebak dengan sifat syirik dan berlaku syirik dikarenakan prilaku itu tidak diperintah Allah, namun mereka tetap dibedakan dari musyrikin, sebab asal

47 Muhammad Husein Thabathaba `i, Op.Cit, h. agama mereka mengikut kitab-kitab yang diturunkan, yang mana pokok ajarannya adalah tauhid bukan syirik. ${ }^{48}$

Lebih lanjut dinyatakan, bahwa $a b l$ al-kitâb dari sisi ini tidak termasuk musyrikin, meskipun kitab yang mereka pegang telah terkontaminasi dengan ajaran syirik. Sama halnya dengan seorang muslim dan umat Nabi Muhammad SAW. tidak dapat disebut seorang yang musyrik, meskipun mereka melakukan tindakantindakan bid'ah dan penyimpanganpenyimpangan dalam beragama, mereka tetap disebut pengikut syari'at tauhid. Begitu pula ketika Allah SWT. memberitakan/menginformasikan tentang komunitas dari pengikut Yahudi dan Nasrani (abl al-kitâb) tidak disebut (أَنَّهُمْ

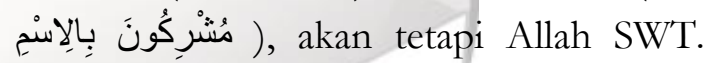

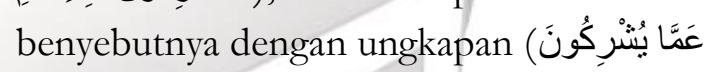
بالْفْعِل dan penggunaan kata benda (al-Isim ) itu lebih kokoh/kuat dibandingkan dengan penggunaan kata kerja (al-fi 'ii). ${ }^{49}$

Di samping itu juga Ibn Taimiyah menambahkan, bahwa ayat 5 dalam surat al-Maidah berfungsi menasakh (mengangkatkan hukum) ayat 221 surat alBaqarah, karena ulama telah sepakat menetapkan surat al-Maidah diturunkan kepada Nabi Muhammad SAW. setelah surat al-Baqarah. Hal ini juga diperkuat dengan hadits:

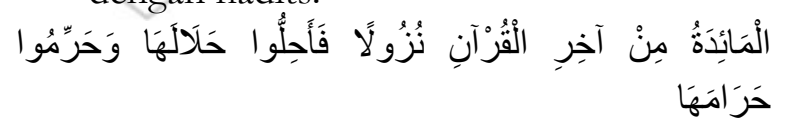

Surat al-Maidah akbir dari al-Qur' an yang diturunkan, karena itu balalkanlab olehmu apa yang telah dibalalkannya (al-Maidah)

48 Taqiyyuddin Abul Abbas Ahmad ibn Abdul Halim ibn Abdus Salam ibn Abdullah ibn Abi al-Qashim ibn Muhammad Ibn Taimiyah, Op.Cit, h. 117

49 Taqiyyuddin Abul Abbas Ahmad ibn Abdul Halim ibn Abdus Salam ibn Abdullah ibn Abi al-Qashim ibn Muhammad Ibn Taimiyah, Op.Cit, h. 117 
dan haramkanlah olebmu apa yang diharamkannya (al-Maidab).

Sehubungan dengan itu digunakan kaidah yang mengatakan apabila terdapat pertentangan antara dua surat, maka ayat yang terakhir diturunkan menasakh ayat yang terdahulu diturunkan. ${ }^{50}$

Untuk memperkuat pernyataan bahwa surat al-Maidah ayat 5 ini turunnya terakhir sudah dekat menjelang wafat Nabi SAW. dapat ditemukan dalam kitab alRaghib oleh imam al-Ashfihani. Menurut Imam al-Ashfihani (w. $502 \mathrm{H}$ ) kata "alyaum" dalam pembukaan ayat merupakan pengulangan dari dari kata yang telah disebut sebelumnya, seperti “ الْيَوْمَ يَيَسَ الَّذِينَ

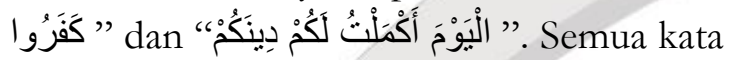

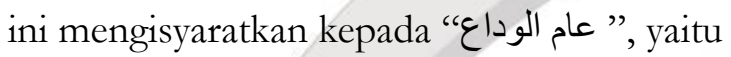
tahun haji wada'. ${ }^{51}$ Haji wada' merupakan haji terakhir/penghabisan yang dilakukan Nabi SAW. bersama sahabat-sahabatnya, dan diperkirakan tiga bulan setelah itu beliau sakit dan akhirnya meninggal dunia.

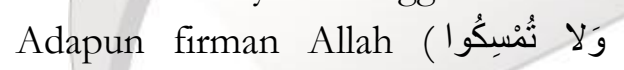

diturunkan setelah perjanjian Hudaibiyah, ketika Nabi SAW. telah hijrah dari kota Makkah ke Kota Madinah lantas Allah turunkan ayat ini dalam rangka memerintahkan kepada Nabi SAW. untuk menguji orang-orang yang ikut hijrah (muhajirin), dan ayat ini berupa khitab (perintah) bagi sahabat-sahabat yang masih mempunyai istri kafir. Dan huruf "al-Lâm" sebagai tanda ma'rifah memfaedahkan "al'Abdu', yang dalam konteks ini khusus ditujukan kepada "al-Musyrikat Arab". Berbaringan dengan itu dalam ayat ditemukan term abl al-kitâb suatu ketika juga

50 Ibid Ma' ruf al-Raghib al-Ashfani, Tafsir al-Raghib al-Ashfahani, (Mesir: Jami atul Thantha, 1420 H - 1999 M), Juz. IV, h. 276

52 Lihat. Q.S. al-Mumtahanah/60: 10 dibedakan dengan term kafir (Q.S. anNisa'/4: 51), dan seperti disebutkan bahwa asal agama mereka adalah iman, akan tetapi mereka telah melakukan kekafiran baik cara keyakinan maupun praktek pengamalannya (Q.S. an-Nisa'/4: 50-51). ${ }^{53}$

Pada akhirnya, untuk memperkuat hukum kebolehan bagi seorang laki-laki muslim menikah dengan wanita abl al-kitâb ada tiga metode yang diperkenalkan ulama, baik ulama tafsir maupun ulama figh, dan menurut hemat penulis metode yang diformulasikan ulama tersebut rasanya sudah memadai untuk memberikan pemahaman tentang kasus ini. Ketiga Metode tersebut adalah sebagai berikut:

Pertama, metode 'Am dan Khas, sebagaimana yang dikemukakan oleh alThabari dalam kitabnya, bahwa ungkapan “ و ولا تتكحوا المشركات حتى يؤمن secara zahir ayat ini memfaedahkan umum, akan tetapi bathinnya (hakekatnya) memfaedahkan khusus dan tidak ada yang dinasikhkan (dihapus hukumnya). Kalimat yang punya maksud seperti itu disebut " العام المخصص ". Dengan demikian kata al-Thabari maksud musyrikat yang benar itu adalah penafsiran imam Qatadah yang mengatakan "wanitawanita musyrik Arab yang mana mereka tidak punya kitab suci untuk mereka baca dalam agamanya". ${ }^{54}$

Kedua, metode nasakh, ulama sepakat mengatakan bahwa ayat 5 surat alMaidah berfungsi menasikh ayat 221 dari surat al-Baqarah. Karena surat al-Baqarah lebih dahulu diturunkan dibanding dengan surat al-Maidah. Untuk memperkuat pernyataan ini ada hadits menjelaskan; "surat al-Maidah termasuk akbir al-Qur'an diturunkan,

53 Taqiyyuddin Abul Abbas Ahmad ibn Abdul Halim ibn Abdus Salam ibn Abdullah ibn Abi al-Qashim ibn Muhammad Ibn Taimiyah, Op.Cit, h. 118

${ }^{54}$ Muhammad ibn Jarir ibn Yazid ibn Katsir ibn Ghalib al-Amaly, Abu Ja'far al-Thabari, Op.Cit, h. 365 
maka halalkanlah olehmu sesuatu yang dihalalkannya dan sebaliknya haramkanlab sesuatu yang diharamkan di dalamnya". ${ }^{55}$ Karena itu, jika ada pendapat yang mengatakan surat al-Maidah itulah yang dinasekhkan, pendapat seperti ini tidak benar karena tidak sesuai dengan sejarah turunnya ayat alQur'an kepada nabi Muhammad SAW. menurut hasil penelitian mayoritas ulama tafsir.

Ketiga, metode istitsna' (pengecualian), metode ini diperkenalkan oleh Ibn Hazm dalam kitabnya sebagai bentuk kompromi (al-jam 'u) terhadap kedua surat tersebut. Ibn Hazm mengatakan bila dirujuk ke dalam al-Qur'an dijumpai firman Allah yang melarang seorang muslim menikahi wanita musyrikat (Q.S. alBaqarah/2: 221). Kalau hanya ini firman Allah, maka pendapat Ibn Umar dapat dibenarkan, akan tetapi kita juga mendapatkan firman Allah yang menghalalkan wanita abl al-kitâb/kitabiyah (Q.S. al-Maidah/5: 5). Cara menyikapi kedua ayat itu kata Ibn Hazm adalah bahwa seorang muslim wajib mematuhi kedua ayat itu tanpa ada yang ditinggalkan satu sama lainnya. Jika dipegang pendapat Ibn Umar, berarti menyalahi ayat ini (Q.S. alMaidah/5: 5) dan hal seperti ini tidaklah boleh. Untuk mengamalkan kedua ayat itu satu-satunya cara adalah dengan menggunakan metode istitsna' (pengecualian), yakni mengecualikan kelompok yang sedikit dari kelompok yang banyak. Maka kesimpulannya wajib mengecualikan kebolehan menikah dengan wanita abl al-kitâb dari keseluruhan jumlah

55 Taqiyyuddin Abul Abbas Ahmad ibn Abdul Halim ibn Abdus Salam ibn Abdullah ibn Abi al-Qashim ibn Muhammad Ibn Taimiyah, Op.Cit, h. 118 keharaman wanita-wanita musyrikat, dan tetap haram selain mereka. ${ }^{56}$

Demikianlah penjelasan tentang status hukum perkawinan antara seorang muslim dengan wanita abl al-kitâb. Berdasarkan paparan penulis di atas agaknya telah tergambar, bahwa abl al-kitâb itu tidak sama dengan musyrik, dan begitupula terkait dengan aspek historis turun ayat, ternyata surat al-Maidah ayat 5 terakhir diturunkan kepada Nabi SAW. dibandingkan dengan al-Baqarah ayat 221. Dengan demikian dapat disimpulkan ayat yang membolehkan menikah dengan wanita abl al-kitâb ini tergolong mubkam (tetap hukumnya) dan sekaligus berfungsi sebagai nasikh (ayat yang membatalkan).

\section{(b). Perkawinan Wanita Muslimah dengan} Laki-laki non Muslim

Setelah dikemukakan bagaimana diskursus dan pendapat tentang hukum perkawinan beda agama antara seorang muslim dengan non muslim, maka pembahasan berikutnya akan menjelaskan bagaimana status hukum perkawinan antara seorang wanita muslimah yang menikah dengan laki-laki non muslim.

Dalam konteks perkawinan wanita muslimah dengan non muslim (abl al-kitâb), secara tekstual (manthuq) tidak ada ditemukan ayat menjelaskan tentang status hukumnya, selain pada kasus Perkawinan dengan orang-orang musyrik, baik yang terdapat dalam surat al-Baqarah ayat 221 maupun yang terdapat dalam surat alMumtahanah ayat 10.

Menurut hemat penulis, bahwa hukum Perkawinan antara seorang wanita muslimah dengan laki-laki non muslim (abl

56 Abi Muhammad 'Ali ibn Ahmad ibn Sa id ibn Hazm, Al-Muhalla, (Beirut: Dâr al-Fikr, t.t), Jld. VI, h. $445-449$ 
al-kitâb) dibolehkan (mubab) selama yang melangsungkan perkawinan itu memenuhi kriteria yang ditunjukkan dalam ayat, yakni al-mubshanât. Untuk memperkuat pendapat ini penulis akan paparkan beberapa dalil dan argumentasi sebagai berikut:

1. Firman Allah dalam surat al-Mumtahanah ayat 10 , stressingnya pada penggalan ayat

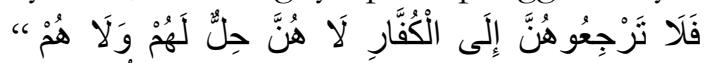

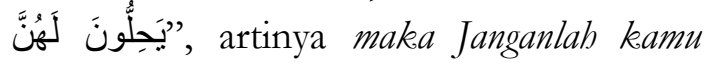
kembalikan mereka kepada suami-suaminya yang kafir, mereka (muslimah) tidak halal bagi mereka orang kafir dan mereka (orang kafir)pun tidak balal pula bagi mereka (muslimah). Ayat ini dijadikan oleh sebahagian ulama untuk menetapkan haram hukumnya menikah seorang muslimah dengan non muslim (abl al-kitâb). Pendapat ini kurang tepat, karena yang dimaksud dengan suaminya yang kafir itu adalah suami-suaminya yang musyrik (kafir musyrik), dan seorang wanita mukminah tidak dihalalkan untuk laki-laki kafir musyrik begitu yang dipahami dari konteks turun ayat dan penafsiran ulama. ${ }^{57}$ Dengan demikian yang diharamkan itu terhadap wanita muslimah adalah menikah dan atau mempertahankan perkawinan dengan laki-laki kafir musyrik yang notabenenya penyembah berhala dan tidak termasuk kafir abl al-kitâb.

2. Dalam kitab Jâmi' al-Bayân disebutkan bahwa ada hadits yang dijadikan pegangan oleh ulama yang mengharamkan Perkawinan antara wanita muslimah dengan laki-laki non muslim, yaitu:

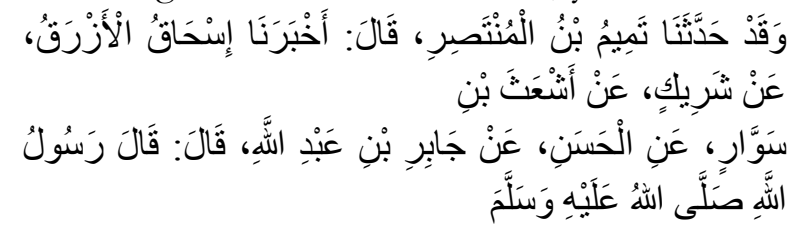

57 Abu Qashim Muhammad ibn Amr ibn Ahmad al-Zamakhasyri, al-Kasysyaf 'An Haqaiqi Ghawamidhi al-Tan₹̂ll, (Beirut: Dar al-kitâb al-'Arabi, 1407), Juz. IV, h. 517 dan Muhammad ibn Ahmad ibn Abi Bakar ibn Farah al-Qurthubi, Op.Cit, Juz. XVIII, h. 66-67

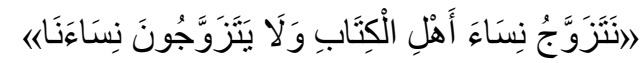
Tamim ibn al-Muntashir telah menginformasikan kepada kami, dia berkata: telah mengkhabarkan kepada kami Ishaq al-Azraq, dari Syurek dari Asy'ats ibn Sawar dari Hasan dari Jabir ibn Abdullah, dia berkata: telah bersabda Rasulullab $S A W$. " Kita boleb menikahi wanita abl al-kitâb, dan sebaliknya mereka tidak boleh menikabi wanita-wanita kita (Islam)". 58

Hadits ini telah ditakhrij ulama seperti yang dikemukan oleh Abu Ja'far, bahwa riwayat ini tidak kuat dijadikan sebagai hujjah, sebab sanadnya bermasalah. Di antara kejanggalan itu, bahwa di dalam mata rantai sanadnya disebutkan bahwa Hasan (Hasan Basri) menerimanya dari Jabir, pada hal Hasan Basri tidak pernah mendengarnya dari Jabir, seperti pernyataan Ali bin al-Madani. Hal ini berarti terputus sanadnya (mursal), yaitu Ibn Abi Hatim. Di samping itu, ada hal lain yang juga menunjukkan bahwa hadits ini tidak dapat dijadikan hujjah, yaitu tidak ditemukan hadits ini dalam kitab-kitab hadits shahih yang dibukukan terkait dengan topik ini. ${ }^{59}$

Dengan demikian dapat disimpulkan bahwa hadits tentang keboleh laki-laki muslim menikah dengan wanita abl alkitâb dan tidak boleh sebaliknya tentu saja tidak dapat dijadikan sebagai dalil, karena kualitas hadits tersebut tergolong kepada dha'if (lemah) dan tidak dapat untuk dijadikan sebagai hujjah dalam kasus ini.

3. Bila diperhatikan ayat-ayat dan haditshadits Nabi SAW. terkait dengan perkawinan banyak berisikan larangan-

${ }_{58}$ Muhammad ibn Jarir ibn Yazid ibn Katsir ibn Ghalib al-Amaly, Abu Ja'far al-Thabari, Op.Cit, Juz. III, h. 716

${ }^{59} \mathrm{Ibid}$, Juz. I, h. 368 
larangan, dibandingkan dengan suruhan/perintah, seperti larangan menikahi dan menikahkan kelompok musyrik (Q.S. al-Baqarah/2: 221), larangan menikahi ibu tiri (Q.S. anNisa'/4: 22), larangan menikahi disebabkan nasab, sepersusuan, dan persemendaan (Q.S. an-Nisa'/4: 23), larangan menikahi wanita-wanita yang bersuami (Q.S. an-Nisa'/4: 24). Begitu pula dengan penjelasan hadits, seperti larangan nikah mut'ah (hadits ke-5115 dalam shahih Bukhari), larangan menghimpun dalam perkawinan antara seorang perempuan dengan bibinya, baik dari pihak ibu maupun dari pihak bapak (hadits ke-5105 dalam shahih Bukhari), dan larangan nikah syigar atau kawin silang (hadits ke- 5112 dalam shahih Bukhari). ${ }^{60}$

Dari sekian banyak dalil-dalil yang melarang tidak ada satu dalilpun yang melarang wanita muslimah menikah dengan laki-laki non muslim (abl al-kitâb). Hal ini mengandung arti bahwa Perkawinan itu termasuk dalam aspek mu amalah yang prinsip dasar hukumnya adalah boleh. Maka dalam hal ini dapat digunakan sebagai pegangan kaidah fiqh : الأصل فى المعاملات الاباحة و الحل (Hukum) asal pada mu'amalah adalab boleh (mubah) dan halal. ${ }^{61}$

Dengan demikian dapat dikatakan bahwa nikah beda agama antara wanita muslimah dengan laki-laki abl al-kitâb (non

60 Muhammad ibn Isma'il Abu Abdillah alBukhari al-Ja'fari, al-Musnad al-Shabih al-Mukbtashar min Umuri Rasulullab wa Sununibi wa Ayyamibi, populer disebut Shabih Bukhari, (Berut: Dar Thuqi an-Najah, 1422), Juz. VII, h. 12

61 Abu Muhammad Shalih ibn Muhammad ibn Hasan Ali Umair al-Asmari al-Qahthani, Majmu' alFawaid al-Babiyah 'Ala Manz̧humah al-Qawâ'id al-Fiqhiyah, (Saudi Arabia: Dâr al-Shami'i li al-Nasyr wa Tauzi', 1420 H/2000 M), Juz. I, h. 75 muslim) tidak ada ditemukan dalil yang melarangnya, maka dapat dikembalikan kepada kaidah di atas yang menetapkan hukumnya adalah boleh (mubah), dan sangat tidak beralasan jika dikatakan bahwa perkawinan seperti itu adalah dilarang (haram).

Berbeda halnya dengan masalah ibadah, dalil-dalil yang menunjukkan tentang ibadah tersebut senantiasa berbentuk perintah, seperti perintah mengerjakan shalat lima waktu (Q.S. alIsra /17: 78), perintah untuk melaksanakan puasa (Q.S. al-Baqarah/2: 183), perintah untuk mengeluarkan zakat (Q.S.alBaqarah/2: 267), dan perintah untuk melaksanakan haji (Q.S. Ali Imran/3: 96). Karena itu jika tidak ada dalil yang memerintahkan, maka perbuatan itu bukanlah disebut ibadah. Sehubungan dengan itu maka ulama menetapkan kaidah: الأصل فى العبادات الحظر , أو الأصل فى العبادات التوقيف Asal pada ibadah itu adalah terlarang (haram), atau asal pada ibadah itu adalah tanqifi (patuh dan mengikut kepada syari' ${ }^{\prime}$ at). ${ }^{62}$

Sehubungan dengan itu seseorang tidaklah dibebani dengan ibadah melainkan setelah ada syari'at dari Allah SW'T serta penjelasan tentang tata caranya. Karena itu terlarang mengerjakan ibadah kecuali setelah ada keterangannya dari syâri (pembuat syari 'at), dan yang mensyari 'atkannya adalah Allah dan Rasul-Nya. Dengan demikian ibadah itu bersifat tauqifi, dalam arti seseorang belum boleh melaksanakannya sampai ada penjelasannya secara langsung dari syari' dan tidak berlaku qiyas atasnya. ${ }^{63}$

62 Muhammad Mushtafa Zuhaili, al-Qawâ'id alFiqbiyah wa Tathbiqâtuha fi Maz̧hbab al-Arba'ah, (Damsyiq: Dâr al-Fikr, 1427 H/2006 M), Juz. II, h. 769

63 Ibid, h. 770 
4. Jika ada pendapat yang tidak membolehkan bentuk perkawinan seperti ini dengan alasan berpegang kepada kaidah:

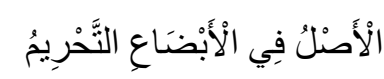

Asal pada al-budbu'(kehormatan wanita) itu adalah haram. ${ }^{64}$

Kaidah ini tentu saja dapat digunakan untuk berhujjah, namun suatu hal yang sangat mendasar untuk dijadikan pertimbangan dan diperhatikan adalah bahwa perumusan sebuah kaidah itu mestilah merujuk kepada petunjuk nashnash yang ada, baik al-Qur'an maupun penjelasan hadits dan tidak boleh berlawanan dengan petunjuk keduanya secara tekstual (manthuq). Hemat penulis kaidah ini perlu dikritisi, sebab tidak sejalan dengan nash, dalam hal ini informasi atau petunjuk yang terdapat dalam surat an-Nisa ayat 22, 23, dan 24.

Dalam ayat 22 dari surat an-Nisa berisikan larangan Allah kepada umat Islam untuk melangsungkan perkawinan dengan wanita yang pernah menikah dengan bapaknya (ibu tiri), seperti firmanNya:

Dan janganlah kamu kawini wanita-wanita yang telah dikeawini oleh ayahmu, terkecuali pada masa yang telah lampau. Sesunggubnya perbuatan itu Amat keji dan dibenci Allab dan seburuk-buruk.jalan (yang ditempub).

Ayat ini secara zahir nash berisikan tentang larangan bagi seseorang untuk melangsungkan perkawinan dengan seorang wanita yang sudah pernah kawin dengan bapaknya (ibu tiri). Bentuk perkawinan seperti ini memang pernah terjadi di masa Jahiliyah, seperti tergambar

64 Abd al-'Aziz Muhammad 'Azam, al-Qawâ'id al-Fiqhiyah, (Kairo: Dâr al-Hadîts, 1426 H/2005 M), h. 525 dalam asbabun nu₹ul ayat, bahwa seorang shahabat Nabi SAW yang bernama Abi Qais ibn Aslat meninggal dunia, lantas anak laki-lakinya meminang mantan isteri bapaknya. ${ }^{65}$ Sehubungan dengan peristiwa itu, maka ayat ini diturunkan untuk mencegah agar perkawinan itu tidak terwujud.

Begitu pula dengan ayat 23 dari surat anNisa ' berisikan larangan untuk mengawini beberapa kelompok wanita-wanita. Menurut al-Shabuni ayat di atas berisikan larangan untuk mengawini beberapa kelompok wanita yang populer disebut muharramat. Didapatkan dalam ayat tersebut tiga bentuk muharramat; (a) muharramat disebabkan adanya hubungan nasab, seperti; ibu, anak perempuan, saudari, bibi (saudari bapak), bibi (saudari ibu), anak perempuan dari saudara lakilaki, dan anak perempuan dari saudari perempuan. (b) muharramat disebabkan adanya hubungan sepersusuan (radha'ab), seperti; ibu sepersusuan, dan saudara sepersusuan. (c) mubarramat disebabkan hubungan persemendaan (mushaharab), seperti; mertua, anak tiri, dan menantu. ${ }^{66}$

Selanjutnya pada ayat 24 kembali disebutkan oleh Allah wanita yang juga dilarang untuk dikawini dan merupakan rangkaian akhir dari ayat-ayat tentang mubarramat (wanita yang haram dinikahi). Dalam ayat ini Allah melarang seorang muslim untuk mengawini wanita-wanita yang masih terikat dengan perkawinan atau wanita-wanita yang punya suami. Hal ini seperti dikemukakan oleh Abu Ja'far $(310 \mathrm{H})$ dalam kitabnya, bahwa pakar tafsir di antaranya Ibn Abbas menafsirkan

65 Abdurrahman ibn Abi Bakar Jalaluddin asSuyuthi, al-Dâr al-Mantsûr fi Tafsir bi al-Ma'tsûr, (Beirut: Dâr al-Fikr, tt), Juz. II, h. 468

${ }^{66}$ Muhammad Ali al-Shabuni, Op.Cit, h. 358- 
kata "al-mubshanât" yang terdapat dalam ayat tertuju kepada wanita-wanita yang punya pasangan. ${ }^{67}$ Imam Ash-Shabuni menambahkan penafsiran kata "almubshanât" itu, yakni wanita-wanita yang punya suami dan wanita-wanita yang sedang menjalani masa iddah. ${ }^{68}$

Sederetan ayat-ayat mubarramat di atas ditutup oleh Allah dengan ungkapan "وأحل لكم ما وراء ذلكم" , artinya: dibalalkan bagimu selain itu. Maksud dari penggalan ayat ini menurut Abu Ja'far adalah pada ayat-ayat sebelumnya Allah telah jelaskan kepada hamba-Nya beberapa kelompok wanita yang dilarang untuk mengawini mereka, maka selain yang tidak disebutkan dalam ayat itu hukumnya adalah dibolehkan (mubab). ${ }^{69}$ Rangkaian ayat ini secara jelas dan pasti memberlakukan untuk objek budhu' atau perkawinan.

Dalam konteks ini Abdul al-Aziz Muhammad 'Azam menjelaskan bahwa wanita-wanita yang diharamkan itu adalah mereka yang tidak halal untuk dinikahi karena ada satu sebab dari beberapa sebab, baik secara mu'abbad (selama-lamanya) maupun secara mu'aqqat (sementara waktu). ${ }^{70}$ Kedua sebab itulah yang dapat dijadikan patokan untuk menentukan haram atau tidaknya suatu perkawinan.

Kaidah di atas juga perlu juga dikritisi dari aspek dalil yang digunakan untuk memformulasikan kaidah tersebut, karena kehadiran sebuah kaidah teraspirasi dari dalil-dalil (al-Qur`an dan Hadits). Munculnya kaidah itu berlandaskan

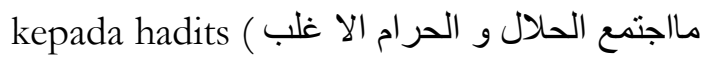
(الحر ام الحلال, artinya; sesuatu yang berbimpun

${ }^{67}$ Muhammad ibn Jarir ibn Katsir ibn Ghalib al-Amaly Abu Ja'far al-Thabari, Op.Cit, Juz. VIII, h. 152

${ }_{68}$ Muhammad Ali al-Shabuni, Op.Cit, h. 360

${ }^{69}$ Muhammad ibn Jarir ibn Katsir ibn Ghalib al-Amaly Abu Ja `ar al-Thabari, Op.Cit, h. 172

70 Abd al-Aziz Muhammad 'Azam, Op.Cit, h. halal dan haram, maka didabulukan yang haram dari halal. Hadits ini ditanggapi oleh tokoh hadits, di antaranya al-Hâfizh Abu al-Fadhl al-'Iraqy yang mengatakan bahwa hadits ini tidak punya asal (لأصل له ). Begitu pula imam Baihaqy memposisikan hadits ini sebagai hadits munqathi ${ }^{71}$ lebih lanjut, bila diperhatikan tahap penerapan kaidah itu dalam masalah furu' menurut penulis tidak tepat untuk kasus ini.

5. Perempuan sama kedudukannya di depan hukum Allah dengan laki-laki, sebagaimana halnya sama dalam menerima taklif, seperti kewajiban shalat, puasa, dan lainnya, kecuali ada dalil khusus yang memperbedakannya, seperti dalam kasus wanita menjadi imam bagi makmum lakilaki, wanita tidak dibolehkan menjadi saksi dalam kasus pidana, perbedaan dalam hal pembahagian kewarisan, dsb. Dalam hal kebolehan wanita menikah dengan lakilaki beda agama tidak ada dalil yang melarangnya sebagaimana dijelaskan di atas.

6. Dalam kajian masâlik al-'illat, salah satunya diperkenalkan oleh ulama ushul fiqh untuk menetapkan suatu hukum yang tidak disebutkan dalam nash, yaitu dengan istilah ilghâ' al-fâriq ( ألغاء الفارق ), maksudnya adalah ditiadakan adanya unsur perbedaan antara ushul dan furu' pada qiyas sehingga hukumnya ditetapkan menjadi sama, atau dengan istilah lain adanya titik perbedaan yang dapat dihilangkan sehingga terlihat kesamaannya. Umpama dalam kasus had qazaf yang tertera dalam Q.S. an-Nur ayat 4. Ayat ini menyatakan tentang wajibnya had qazaf (had tuduhan) bagi seorang laki-laki yang

${ }^{71}$ Jalaluddin Abd al-Rahman bin Abi Bakar alSuyuthi, al-Asybah wa al-Nabzâir, (Indonesia: Maktabah wa mathba'ah Thaha Putra Semarang, tth.), h. 74-75 dan bandingkan Abd al-Aziz Muhammad 'Azam, Op.Cit, h. 525 
menuduh wanita baik-baik berbuat zina dan sebaliknya ayat tidak ada menerangkan (maskutu 'anbu) dalam kasus apabila wanita yang menuduh pria baikbaik berbuat zina. Maka dalam hal ini perbedaan jenis kelamin itu mesti dihilangkan atau ditiadakan sekaligus diberlakukan hukum yang sama, yaitu sama-sama mendapatkan had qazaf yang ditetapkan dengan menggunakan metode ilghâ alfâriq (الغاء الفارق), sebab harga diri atau harkat dan martabat antara laki-laki dan perempuan sama di mata hukum Islam. $^{72}$

Sama halnya dengan penjelasan alQur'an tentang Perkawinan beda agama yang terdapat dalam Q.S. al-Maidah ayat 5. Ayat ini menerangkan bahwa perempuan abl al-kitâb dihalalkan/dibolehkan bagi laki-laki muslim untuk dinikahi, dan ayat tidak ada menerangkan bagaimana dengan laki-laki abl al-kitâb menikah dengan wanita muslimah. Dalam kasus ini dapat digunakan pula cara ilgha' al-Fariq ( ألغاء (الفارق ), artinya perbedaan jenis kelamin dalam kasus ini mesti dihilangkan sehingga hukumnya dapat diberlakukan sama. Kalau zahir ayat membolehkan laki-laki muslim menikah dengan wanita abl al-kitâb yang mubshanat (wanita merdeka dan terhormat), maka begitupula dengan wanita muslimah juga dibolehkan melangsungkan Perkawinan dengan lakilaki yang mubsinin (laki-laki merdeka dan terhormat) dari kalangan abl al-kitâb.

Untuk memperkuat kebolehan ini adalah wanita yang hidup di zaman

\footnotetext{
72 Wazaratul Auqaf wa al-Syu unu al-Islamiyah, al-Mausû ah al-Fiqhiyah al-Kuwaitah, (Kuawit: Dar alSalasil, 1404-1427 H), Juz. VI, h. 187-188 dan bandingkan Abu Abdillah Badruddin Muhammad ibn Abdullah ibn Bihadir al-Zarkasyi, al-Babru al-Mubîdh fi Ushul al-Figh, (Beirut: Dar al-Kutubi, 1414 H / 1994 M), Juz. VII, h. 325-326 dan juga Amir Syarifuddin, Ushul Fiqh, (Jakarta: Kencana, 2009), Cet. IV, h. 236-237
}

modern ini jauh berbeda dengan kehidupan wanita ketika turun wahyu dan sampai di era modern.

Analisis lain juga dapat dipahami dari penggunaan kata الحلال, seperti terungkap dalam ayat 5 surat al-Maidah. Syafi $i$, Malik, dan Ahmad mengatakan bahwa kata halal itu adalah segala sesuatu yang tidak ada dalil yang mengharamkannya. Sementara menurut Abu Hanifah halal itu adalah sesuatu yang ada dalil yang menunjukkan halalnya. Sehubungan dengan itu Allah SWT telah membolehkan/menghalalkan segala sesuatu dan hanya mengharamkan sebahagiannya. Di samping itu, ada hal-hal yang oleh syâri' (Allah dan Rasul-Nya) didiamkan ( المسكوت عنه ), artinya tidak ada nash yang membolehkan dan mengharamkan, maka dalam hal ini menurut Jumhur ulama hukumnya adalah boleh. ${ }^{73}$

Dalam konteks perkawinan antara wanita muslimah dengan laki-laki non muslim (abl al-kitâb) tidak ada nash melarang dan menyuruh, maka kasus ini termasuk ke dalam persoalan yang didiamkan oleh syâri' ( المسكوت ع ), maka sesuai dengan konsep jumhur ulama selama tidak ada nash yang melarang dan menyuruh perkawinan dalam bentuk ini, maka dapat ditetapkan bahwa perkawinan semacam ini hukumnya adalah mubah/halal.

Demikianlah sederatan dalil dan argumentasi yang dapat penulis sajikan untuk menjawab kasus perkawinan beda agama di Indonesia menurut perspektif hukum Islam. Mencermati sederetan dalil dan alur fikiran yang dikemukakan di atas, maka menurut hemat penulis sangat beralasan jika dikatakan bahwa perkawinan beda agama itu dibolehkan, baik yang dilakukan oleh laki-laki muslim dengan wanita non muslim dan begitu juga sebaliknya, selama memang memenuhi kriteria seperti tertera dalam ayat, yakni mubsanat

73 Muhammad Mushtafa Zuhaili, al-Qawâid alFiqhiyah wa Tathbiqâtuha, Op.Cit, h. 190 
(merdeka dan terhormat/terpelihara kehormatannya).

Pembahasan selanjutnya penulis akan memberikan tanggapan dan kritikan terhadap pendapat ulama-ulama di Indonesia yang tergabung dalam kelompok-kelompok keislaman. Pada umumnya ulama-ulama tersebut sepakat menetapkan haram hukumnya seorang muslim menikah dengan non muslim di Indonesia.

Menurut penulis jika yang dibahas dan ingin diketahui kedudukan hukum perkawinan beda agama, maka dalil naqli yang berupa ayatayat al-Qur'an yang digunakan sebagai dalil cukup tiga surat dan ayat saja yang relevan dengan objek kajian, yakni Q.S. alBaqarah/2:221, Q.S. al-Mumtahanah/60: 10, dan Q.S. al-Maidah/5: 5. Ketiga ayat inilah sentral untuk menentukan boleh atau tidaknya hukum perkawinan beda agama, dengan mempertanyakan apakah agama- agama di Indonesia termasuk kelompok musyrik atau termasuk kelompok abl al-kitâb. Hal mendasar lagi makna yang terkandung dari kata musyrik itu apa dan makna abl al-kitâb itu apa. Selanjutnya dikaji dengan mendalam bagaimana aspek historis dan konteks sosial ketika ayat itu diturunkan. Dan juga tidak kalah pentingnya untuk dipahami adalah aspek munasabahnya.

\section{Kesimpulan}

Setelah melakukan penelusuran bab demi bab, maka dipenghujung pembahasan ini dapat diformulasikan beberapa intisari dari hasil penelitian yang tertuang dalam bentuk kesimpulan sebagai berikut:

1. Agama-agama yang berkembang dan dianut oleh masyarakat Indonesia, selain agama Islam seperti, Katolik, Kristen Protestan, Hindu, Budha, dan Konghucu dapat digolongkan ke dalam kelompok abl

al-kitâb, dengan alasan agama-agama tersebut akar kepercayaannya menganut paham monoteisme (taubid) dan dalam hal pengamalan agamanya mereka memiliki dan membaca kitab suci.

2. Undang- Undang yang mengatur perkawinan di Indonesia, yaitu UU No. 1 Tahun 1974 tidak mengatur secara tegas kasus perkawinan bagi penduduk yang berbeda agama, sehingga menimbulkan ketidakpastian hukum yang pada akhirnya memerlukan kebijakan hukum dari Mahkamah Agung (MA). Meskipun demikian Pengaturan perkawinan beda agama di Indonesia masih bersifat ambivalen.

3. Setelah melakukan penelitian atau ijtihad dengan menggunakan pendekatan ushul fiqh terhadap kasus perkawinan beda agama yang terjadi di Indonesai, maka pada akhirnya dapat disimpulkan bahwa perkawinan tersebut hukumnya mubah (boleh) dengan syarat memenuhi keriteria kebolehan yang terdapat dalam nash, yakni almubshanât (merdeka dan memelihara kehormatan diri).

Sehubungan dengan ketidak tegasan pemerintah Indonesia dalam hal mengatur kasus perkawinan beda agama dengan indikator tidak adanya pasal khusus yang melarang dalam Undang-Undang No. 1 Tahun 1974, maka penulis melalui penelitian ini menyarankan hal-hal sebagai berikut:

1. Mendesak untuk segera dilakukan amandemen atau revisi terhadap Undang-Undang No. 1 tahun 1974 dengan memasukkan satu pasal 
khusus yang menegaskan aturan perkawinan beda agama di Indonesia, agar kasus perkawinan beda agama ini mendapatkan kejelasan dan kepastian hukum, sehingga kasus ini tidak selalu menjadi perdebatan yang senantiasa meresahkan masyarakat.

2. Perlu dilakukan pertemuan tokohtokoh agama untuk mendiskusikan serta merumuskan tentang perkawinan beda agama sebab secara umum ajaran-ajaran agama yang berkembang di Indonesia masih membuka peluang untuk melangsungkan perkawinan dengan bentuk ini sehingga masing-masing pemeluk agama akan memahami dan menyadari ajaran agamanya.

3. Diharapkan kepada ulama-ulama dan tokoh-tokoh Islam yang telah mengeluarkan fatwa haramnya hukum perkawinan beda agama agar melakukan peninjauan kembali fatwanya dengan cara mengedepankan ijtihad istinbathi terhadap ayat-ayat al-Qur'an dan Sunnah Nabi Saw. dan bukan semata-mata mengedepankan mashlabah seraya mengenyampingkan nash alQur`an dan hadits.

\section{DAFTAR PUSTAKA}

Al-Qur`an al-Karîm

Abu Abdillah, Muhammad ibn Yusuf ibn Abi Qashim al-Badri. tth. al-Tâj wa al-Iklil li Mukhtasar Khalil, Beirut: Dar al-Fikr

Abu Hamid, Muhammad ibn Muhammad AlGhazali. 1417. al-Wasith fi al-Madžbab, Kairo: Dar al-Islam
Abu Hayyan, Muhammad ibn Yusuf ibn Ali ibn Yusuf. tth. al-Babr al-Mubith, Beirut: Dar al- Fikr

Abu Rayyah, Muhammad. 1970. Din Allab alWâhid, Kairo: Alam al-Kutûb

Abu Syuhbah, Muhammad ibn Muhammad. 1992 M/1412 H. al-Madkhâl li Dirâsati alQur'an al-Karim, Kairo: Maktabah asSunnah

Abu Zahrah, Muhammad. 1996. Aliran Politik dan Aqidah, terj. Abdur Rahman Dahlan dan Ahmad Qarib, Jakarta: Logos 1904. Al-Mubâdharat fi Al-Nashraniyat, Riyadh: tp.,

Madzâhbib al-Islamiyah, Mesir: Dar al-Fikr al-'Arabi

Ahmad, Kamaruzzaman Bustaman. 2004. Wajah Baru Islam di Indonesia Yogyakarta: UII Press

Ahmad, Kursyid. 1404. Limâza Aslama, Riyadh: Dar al-Ifta

Abu Ahmadi. 1970. Perbandingan Agama, Jakarta: Rineka Cipta

Ali, Shahil Ibn Su'ud. tth. al-Tamassake bi alSunnah wa Atsâribi fi Istiqâmah al-Muslim, Riyadh: Majalah al-Buhuts al-Islamiyah

Ali, Maulana Muhammad. 1993. Quran Suci: Teks Arab Terjemah dan Tafsir, terj., Yogyakarta: Pustaka Pelajar

Ali, Mukti. 1991. Memahami Beberapa Aspek Ajaran Islam, Bandung: Mizan

Anshari, Ibn Munzir. th. Lisan al-'Arabi, Kairo: Dar al-Mishriyah

Alusi al-Baqdadi, Abi Fadhl Syihab al-din alSa id Muhammad. 1994. Rûh al Ma'ânifi Tafsir al-Qur'an al-'Az̧îm wa Sab'u alMatsâni, Beirut: Dar al-Fikr

Amin, Ahmad. tth. Dhuba al-Islâm, Mesir: Maktabah al-Nahdhah al-Misriyah

Anas, Malik ibn. tth. al-Mudawwanah al-Kubra, Kairo: Dar al-Fikr 
Ansari, Endang Saifuddin. 1991. Wawasan Islam; Pokok-Pokok Pikiran tentang Islam dan Umatnya, Jakarta: Rajawali Pers

Anshary, Hafiz. 1996. Problematika Hukum Islam Kontemporer, Jakarta: Pustaka Firdaus

Anshor, Maria Ulfah dan Martin Lukito Sinaga. 2004. Tafsir Ulang perkawinan Beda Agama; Perspektif Perempuan dan Pluralisme, Jakarta: KAPAL Perempuan

Arifin, M.1987. Menguak Misteri Ajaran-Ajaran Agama Besar, Jakarta: Golden Terayon Press

Asfahaniy, al-Râghib. 1961. al-Mufradât fi Gharib al-Qur'an, Mesir: Mushthafa alBabi al-Halabi

Ashbahi al-Madani, Malik ibn Anas ibn Malik ibn Amir. tth. Muwatha Malike ibn Riwayati Mubammad ibn Hasan al-Syaibani, Kairo: Al-Maktabah Al-Ilmiyah

'Azam, Abd al-'Aziz Muhammad. 1426 H/ 2005 M. al-Qawa'id al-Fiqhiyah, Kairo: Dâr al-Hadîts

Azra, Azyumardi. 1994. Jaringan Ulama Timur Tengah dan Kepulauan Nusantara Abad XVII-XVIII, Bandung: Mizan

Baghawi, Abu Muhammad al-Husen ibn Mas`ud. 1417 H/1997 M. Ma'âlim atTanzîl fi Tafsir al-Qur'an, (Tafsir alBaghawi), Beirut: Dar Thayyibah wa atTauzi

Badran, Abu al-'Aynayn Badran. 1984. al¿Alâqât al-Ijtima iyjah Bayna al-Muslimin wa Ghaiyr al-Muslimin, Iskandariyah: Mu`assasah Syabab al-Jam `iyah

Baqi, Muhammad Fuad. 1987. al-Mujam alMafahrâs li al-Fâž̉ al-Qur'an, Beirut: Dar al-Fikr

Baghdadi, Abu Mansur Abdul Qahir ibn Thahir ibn Muhammad ibn Abdullah. 1977. al-Farq Baina al-Firâq wa Bayân alFurqah al-Najizah, Beirut: Dar al-Afaq alJadidah
Baruszi, Ismail Haqiy. tth. Tafsir al-Rûh alBayân, Beirut: Dar al-Fikr

Cawidu, Harifuddin. 1991. Konsep Kufr Dalam al-Qur'an, Jakarta: Bulan Bintang

Darmabrata, Wahono. 2003. Tinjauan UndangUndang No. 1 Tabun 1974 Tentang Perkawinan Beserta Undang-Undang dan Peraturan Pelaksanaannya Jakarta: Gitama Jaya

Dawalibi, Ma'ruf. 1965. al-Madkbâl fi 'Tlmi Ushûl al-Figh, Beirut: Dar al-Kitab alJadid

Departemen Agama RI. 1992/1993. Kompilasi Hukum Islam di Indonesia,(Jakarta: Dirbenpera Dirjen Pemibnaan Kelembagaan Agama Islam Departemen Agama RI.

Departemen Pendidikan dan Kebudayaan. 1991. Kamus Besar Bahasa Indonesia, Jakarta: Pusat Pemibnaan dan Pengembangan Bahasa Indonesia

Djamil, Fathurrahman. 1995. Metode Ijtihad Majlis Tarjih Mubammadiyah, Jakarta: Logos Publishing House

Eoh, O.S. 1996. Perkawinan Antar Agama Dalam Teori dan Praktek, Jakarta: Raja Grafindo Persada

Farmawi, 'Abd al-Hayy. 1977. al-Bidâyah fi Tafsir al-Maudhu iy, Qahirah: al-Hadharah al-`Arabiyyah

Fridolin, Ukur. 1987. Beberapa Catatan Pibak Protestan Mengenal Hasil Dialog KWI-PGI Tentang Kawin Campur, Jakarta: Buletin Hak Kerukunan, Komisi Hak KWI

Hazly, Ja'far ibn al-Hasan (Imamiyah). tth. Syarai al-Islâm fi Masâil al-Halal wa alHaram, Mesir: Mu'assasah Mathbu`aty Isma iliyah

Hakim, Abdul Hamid. 1977. al-Mu'în al-Mubîn, Jakarta: Bulan Bintang

Haidar, M. Ali. 2000. Nahdhatul Ulama dan Islam di Indonesia, Jakarta: Gramedia Pustaka Utama 
Haikal, Muhammad Husein. 1977. Hayyu Mubammad, Kairo: Dar al-Ma'rifah

Hanafi, A. 1970. Pengantar dan Sejarah Hukum Islam, Jakarta: Bulan Bintang

Haryono R.,Yudhie. 2002. Post Islam Liberal, Bekasi: Airlangga Pribadi

Hasan, Ali. 1995. Perbandingan Mą̧ab, Jakarta: Raja Grafindo Persada

Hasan, Hasan Ibrahim. 1979. Târikh al-Islâm,

Mesir: Maktabah al-Nahdhah al-Misriyah

Hazairin. 1986. Tinjanan Mengenai UndangUndang Perkawinan No 1/1974, Jakarta: Tintamas

---------. 1961. Hukum Kekeluargaan Nasional Indonesia, Jakarta: Tintamas

Hitti, Philip K. 1974. History of Arabs, ed. IX, ttp: The Macmillan Press Ltd

Hosein, Ibrahim. 1971. Fikib Perbandingan Dalam Masalah Nikah, Talak, dan Rujuk, Jakarta: Ihya Ulumuddin

Husaini, Adian dan Nuim Hidayat. 2003. Islam Liberal: Sejarah, Konsepsi, Penyimpangan dan Jawabannya. Jakarta: Gema Insani Press

Husein, M. al-Hamid. 1992. Sirah al-Musthafa, Jakarta: al-Madani

Ibn 'Arabi, Abu Bakar Muhammad ibn Abdullah. tth. Abkâm al-Qur'an, Beirut: Dar al-Fikr

Ibn al-Humam. 1970. Syarh Fath al-Qadîr, Kairo: Mushtafa al-Baby al-Halaby

Ibn Hazm, Abi Muhammad 'Ali ibn Ahmad ibn Sa id. tt. Al-Muballa, Beirut: Dar alFikr

Ibn Hisyam. tth. Sirah al-Nabawiyah, Beirut:

Dar al-Fikr

Ibn Jauzi, Jamaluddin Abu Farh Abdurrahman ibn Muhammad. 1422 H. Zad al-Masî fi Tlmi Tafsir, (Beirut: Dar al-Kitab alArabi

Ibn Katsir, al-Qarsy ad-Dimasyiqy, Imaduddin Abi Fidâ`Isma'il Ibn 'Umar. 1418. Tafsir al-Qur'an al-'Az̧him, (Tafsir Ibn Katsir), Riyad: Dar al-Salam Linasyri wa Tawzi'
Beirut: Dar al- Fikr

Ibn Qudamah, Abu Muhammad, Abdullah ibn Ahmad al-Muqaddisi. 1405 H/1985 M. al-Mughni Syarb Mukbtasar al-Kharqi, Beirut: Dar Ihya`at-Turats al-`Arabi , Abdurrahman ibn Muhammad alMuqadisi. tth. al-Mughni, Riyadh: Maktabah Ar-Riyadh Al-Hadîtsah

--------, Maufuqiddin Abu Muhammad al-Muqadisi. tth. al-Kafi Fi Figh al-Imam Ahmad, Beirut: Dar al-Fikr

Ibn Qayyim, Jauziyah. 1970. Zâd al-Ma ad fi Huda Khair al-Ibâd, Kairo: Musthafa alBabi al-Halabi

Ibn Taimiyah, Taqiyyuddin Abul Abbas Ahmad ibn Abdul Halim ibn Abdus Salam ibn Abdullah ibn Abi al-Qashim ibn Muhammad. 1408 H/ 1987 M. alFatawâ al-Kubrâ Li Ibni Taimiyah, Kairo: Dar al-Kutub al-'Ilmiyah

Jashshash, Abi Bakar Ahmad ar-Razi. 1993. Abkâm al-Qurian, (Tafsir al-Jashash), Beirut: Dar al-Fikr

Jaziri, Abdur Rahman. 1990. Kitab al-Figh 'Ala al-Madrâabib al-'Arba'ah, Beirut: Darul Kutub Al-Ilmiah

Jubba `iy, Zainuddin ibn Ali al-Amaly (Imamiyah). tth. al-Raudhah al-Babiyah fi Syarh al-Lumiah al-Damsyiqiyah, Beirut: Dar al-'Alam al-Islamiy

Kasani, Abu Bakar ibn Mas 'ud. 1418 H/1997 M. Badâi al-Shanai' fi Tartib al-Syarai', Beirut: Dar al-Kutub al-Ilmiyah

Khathib, Muhammad Asyarbini. tth. Mughni alMubtâj, Mesir: Dar al-Fikr

Kahlani, Muhammad ibn Ismail. 1344/1929. Subul al-Salam, Bandung: Maktabah Dahlan

Khallaf, Abdul Wahab. 1973. Ilmu Ushûl Fiqh, Jakarta: Dar al-Manar 1974. Khulashah Tarikh

Tasyri' al-Islami, terj. A. Aziz Masyhuri, Semarang: Ramadhani

Fenomena Perkawinan Beda. 
Khalafuddin, Muhammad Ahmad. 1984. Majelis Ulama Indonesia (MUI).1995. Mafâhim Qur'aniyah, Kuawit: al-Majlis al- Himpunan Keputusan dan Fatwa Majelis Wathny

Khaluti, Isma`il Haqy ibn Musthafa alIstanbuly al-Hanafi. tth. Rûh al-Ma'âni, Beirut: Dar al-Fikr

Khathîb, Muhammad 'Ajâj. 2006 M/1427 H. Ushûl al-Hadîts, 'Ulûmubu wa Mushthalah, Beirut: Dâr al-Fikr

Khatib, Abd. al-Karim. 1981. al-Din Dharurat Hayat al-Insan, Riyadh: Dar al-Ishalat li al-Tsaqafat wa al-Nasyr wa al-Islam

Khazen, Ali ibn Muhammad ibn Ibrahim ibn Amr al-Syihi Abu Hasan. $1415 \mathrm{H}$. Lubâbu al-Ta' 'wil fi Ma' âni al-Tanžl, (Tafsir al-Khazen), Beirut: Dar al-Kitab alIlmiyah

Maushuli, Ibn Maududi. tth. al-Ikbtibar li alTa'lil al-Mukhtar, Beirut: Dar al-Fikr

M. Rasjidi. 1974. Kasus RUU Perkawinan dalam Hubungan Islam dan Kristen Jakarta: Bulan Bintang

Ma'luf, Louis. tth. al-Munjid fi al-Lughah wa alA 'lam, Beirut: Dar al-Syuru'

al-Mizi, Yusuf ibn Abd al-Rahman ibn Yusuf.1400 H/1980 M. Tabdž̨b al-Kamal fi Asma' al-Rijâl, Beirut: Mu`assasah Risalah

Madjid, Nurcholish. 1992. Islam Doktrin dan Peradaban, Jakarta: Yayasan Waqaf Paramadina

Mahally, Jalaluddin. tth. Syarb Minbâj alThâlibin, Mesir: Dar al-Ihya`al-Kutûb alKubra

Mahfudh, Sahal. 2005. Solusi Problematika Aktual Hukum Islam; Keputusan Muktamar Munas, dan Konbes Nabdhatul Ulama 19261999 M. ,Jawa Timur: Lajnah Ta'lif Wan Nasyr NU

Mahmud al-Alusi, Syihabuddin al-Sayyid. tth. Rûb al-Ma' ani fi Tafsir al-Qur'an al-' Adzîm wa al-Sab'u wa al-Matsani, Beirut: Dar alFikr

Ulama Indonesia, Jakarta: Sekretariat Majelis Ulama Indonesia Majid Istiqlal

Manan, Abdul dan M. Fauzan. 2002. PokokPokok Hukum Perdata: Wewenang Peradilan Agama, Jakarta: Raja Grafindo Persada

------. 2006. Aneka Masalah Hukum Perdata Islam di Indonesia, Ed. I, Jakarta: Kencana

Maraghi, Ahmad Mushthafa. 1394 H/ 1984 M. Tafsir al-Marâghi, Beirut: Dar al-Fikr

Masjfuk Zuhdi. 1993. Masâil al Fighiyah, Jakara:

Haji Masaung

Mathrohy, Mahmud. 1996. al-Majmu' Syarh alMubadzab, Beirut: Dar al-Fikr

Maududi, Abu al-A'la. 1983. al-Islâm fi Muwajahah al-Tahaddiyah al-Mu'asharah, Kuait: Dar al-Qalam 1985. Prinsip-Prinsip Islam, terj. Abdullah Suhaimi, Bandung: Ma'ârif

Mertokusumo, Sudikno. 2002. Mengenal Hukum, Yogyakarta: Liberty Yogyakarta

Mudzhar, M. Atho`. 2000. Membaca Gelombang Ijtibad; Antara Tradisi dan Liberasi, Yogyakarta: Titian Ilahi Press

1993. Fatwa-fatwa Majelis Ulama Indonesia: Studi tentang Pemikiran Islam di Indonesia 1975-1988, Jakarta: INS

Muhaimin, dkk. 1994. Dimensi- Dimensi Studi Islam, Surabaya: Karya Abditama . 2005. Kawasan dan Wawasan Studi Islam, Jakarta: Kencana

Muhammad Ali, Maulana. 1977. The Religion of Islam, terj. R. Kaelan dan H.M. Bachrun dengan judul: Islamologi, Jakarta: Ikhtiar Baru

Muhsin, Muhammad Salim. tth. Târikh alQur'an al-Karim, Iskandariyah: Muassasah Syabab al-Jam'iyah

Na'im, Abdullah Ahmed.2001. Dekonstruksi Syari'ah, Jakarta: LkiS 
Nafrawi, Ahmad ibn Ghanim ibn Salim. th. alFawakibu ad-Dawani 'Ala Risalati Ibn Abi Zaid al-Qairawani, Kairo: Maktabah alTsaqafah al-Diniyah

Najdi al-Hanbali, Abd al-Rahman Ibn Muhammad ibn Qashim al-'Ashimi. 1398. Majmu' Fatawa Syekh al-Islâm Ibn Taimiyah, Beirut: Dar al-'Arabiyah li alThiba' ah wa al-Nasy wa al-Tawzi'

Nasution, Harun, dkk. 1992. Ensiklopedi Islam Indonesia, Jakarta: Djambatan

Noer, Deliar. 1982. Gerakan Islam Modern di Indonesia 1900-1942, Jakarta: LP3ES

Nuruddin, Amiur dan Azhari Akmal tarigan. 2006. Hukum Perdata Islam di Indonesia, Jakarta: Kencana

Pagar. 2006. Perkawinan Berbeda Agama W acana dan Pemikiran Hukum Islam Indonesia, Bandung: Cita Pustaka Media

Purwaharsanto pr. 1992. Perkawinan Campuran Antar Agama menurut UU RI No. 1 Tabun 1974 tentang Perkawinan: Sebuah Telaah Kritis Aktualita Media Cetak, Yogyakarta: tnp,

Purwardaminta,W.J.S. 1997. Kamus Besar Bahasa Indonesia, Jakarta: Departeman Pendidikan dan Kebudayaan

Qaradhawi, M. Yusuf. 2010. Halal dan Haram, Jakarta: Robbani Press

Qashimi, Muhammad Jamaluddin. 1377 H/ 1958 M. Mahâsin al-Ta'wil, (Tafsir alQashimi), Kairo: 'Isa al-Babi al-Halabi

Qaththan, Manna' Khalil. 1981. Mabâhits fi Ulûm al-Qur'an, Riyadh: Maktabah Ma'arif

Qodir, Zuli. 2003. Islam Liberal: Paradigma Baru Wacana dan Aksi Islam Indonesia, Yogyakarta: Pustaka Pelajar

Qurthubi, Muhammad ibn Ahmad ibn Abi Bakar ibn Farah. 1407 H/1987 M). alJâmi li Abkâm al-Qur'an, Beirut: Dar alFikr
Rahman, Asmuni Abdul. 1985. Majlis Tarïh Mubammadiyah, (Yogyakarta: lembaga Research dan survey IAIN Sunan Kali Jaga

Ramulyo, Mohd. Idris. 1996. Hukum Perkawinan Islam: Suatu Analisis dari Undang- Undang No 1 Tabun 1974 dan Kompilasi Hukum Islam, Jakarta: Bumi Aksara

2004. Hukum Perkawinan Islam, Jakarta: Bumi Aksara

Razy, Abu Abdullah Muhammad ibn Amr ibn Hasan ibn Husein al-Taymi. 1420. Mafâtîh al-Ghaib (Tafsir al-Kabir), Beirut: Dâr Ihyầ al-Turâts al-' Arabî

Redaksi Indonesia Tera. 2010. UUD 1945 హ Perubahannya + Struktur Ketatanegaraan, Yogyakarta: Indonesia Tera

Ridha, Muhammad Rasyid. 1960. al-Wabyu alMubammadiy, Kairo: Maktabah alQâhirah

1990. Tafsir alQur'an al-Hakim, Mesir: Al-Haìah AlMishriyah Al-'Ammah li Al-Kitab

Rofiq, Ahmad. 2004. Fiqh Kontelestual: dari Normatif ke Pemaknaan Sosial, Yokyakarta: Pustaka Pelajar

Romli, Lili. 2006. Islam Yes Partai Islam Yes, Jakarta: Pustaka Pelajar

Sabiq, Sayyid. 1403 H/1983 M. Figh al-Sunnah, Berut: Dar al-Fikr

Salim HS. 2002. Pengantar Hukum Perdata Tertulis (BW), Jakarta: Sinar Grafika

Sarakhasi, Muhammad ibn Ahmad ibn Abi Sahal. 1989. al-Mabsûth, Beirut: Dâr alMa'rifah

Shabuni, Muhammad Ali. 1422/2001. Rawâi' al-Bayân Tafsir Ayâti al-Abkâm min alQur'an, Jakarta: Dâr al-Kitâb al-Islamiyah Ash-Shiddiqi, Hasbi. 1980. Sejarah dan Pengantar Ilmu Hadits, Jakarta: Bulan Bintang al-Sâyis, Muhammad Ali. 1995. Pertumbuban Dan Perkembangan Hukum fiqh; Hasil Refleksi Ijtihad, judul asli: Nasy atu al-Fiqh 
al-Ijtihâdi wa Athwârubu, Jakarta: Raja Grafindo Persada

Shihab, M. Quraish. 2003. Wawasan Al-Qur'an;

Tafsir Maudhû'i atas Pelbagai Persoalan Umat, Bandung: Mizan 1992. Membumikan Al-

Qur an, Bandung: Mizan -. 2000. Tafsir Al-Mishbab;

Pesan, Kesan dan Keserasian al-Qur'an, Jakarta: Lentera hati

Soimin, Soedharyo. 2002. Hukum Orang dan Keluarga, Jakarta: Sinar Grafika

Sosroatmodjo, Arso dan A. Wasit Aulawi. 1978. Hukum Perkawinan di Indonesia Jakarta: Bulan Bintang

Suryanegara, Ahmad Mansur. 1996. Menemukan sejarah, Bandung: Mizan

Sayuthi, Abdurrahman ibn Abi Bakar Jalaluddin. 1403 H/ 1983 M. al-Dar alMantsûr fi al-Tafsir al-Ma'tsûr, (Beirut: Dar al-fikr

Syafi i, Muhammad ibn Idris. tth. al-Um, Beirut: Dar al-Fikr

Syahrastani, Abu al-Fath Muhammad ibn Abdul Karim ibn Abi Bakar Ahmad. th. al-Milal wa an-Nibal, Berut: Dar al-Fikr

Syaltut, Mahmud. 1966. al-Fatâwa, Kairo: Dar al-Qalam

1966. Islâm Aqîdab wa

Syari' ah, Mesir: Dar al-Qalam

Syarif, Mahmud. 1979. al-Adyân fi al-Qur'an, Jakarta: Dâr Ukaizh

Syarifuddin, Amir. 2009. Hukum Perkawinan Islam di Indonesia; Antara fiqh Munakahat dan Undang-Undang Perkawinan, Jakarta: Kencana

Kencana

Syathibi. tth. al-Muwâfaqât fi Ushûl al-Syari'ah, Kairo: Maktabah Rahmaniyah

Syaukani, Muhammad ibn Ali. 1993. Fath alQadîr, Beirut: Dar al-Fikr

Syikati, Abdul Fatah Ali. 1975. Tarikh al-Ummat al-'Arabiyah, ttp: Matba'ah
Thabathaba i, Muhammad Husein. 1991. alMĩâan fi Tafsir al-Quran, Beirut: Mu assasah al-A `la li al-Mathbu`at

Thabary, Muhammad ibn Jarir ibn Yazid ibn Katsir ibn Ghalib al-Aamaliy, Abu Ja'far. 1420/2000. Jâmi' al-Bayân fi Ta wîl alQur`an, Beirut: Mu`assasah al-Risalah

------1 1979. Târikh al-Umam wa al-Mulûk, Beirut: Dar al-Fikr

Tim Citra Umbara. 2010. Undang- Undang Republik Indonesia Nomor 1 Tabun 1974 Tentang Perkawinan dan Kompilasi Hukum Islam, Bandung: Citra Umbara

Tim Departemen Agama RI. 1985. Ushul Fiqh I, Jakarta: Proyek Pembinaan Prasaran dan Saran PTA

Tsa `abi, Abu Zaid Abd Rahman ibn Muhammad ibn Makhluf. 1418 H. alJawâhir al-Hasan fi tafsir al-Qur'an, Beirut: Dâr Ihya` al-Turats al-'Arabi

Usman Adji, Sution. 1989. Kawin Lari dan Kawin Antar Agama, Yogyakarta: Liberty Yogyakarta

Verkuyl. 1989. Etika Kristen Seksuil, Jakarta: BPK Gunung Mulia

Wahab, Rochidin. 2004. Sejarah Pendidikan Islam di Indonesia, Bandung: Alfabeta

Wahidi. 1968. Asbab an-Nuqûl; edisi ke-2, Mesir: Musthafa al-Bab al-Halabi

Wajdi, Muhammad Farij. th. Dairah Ma'arif: alQarn al-'Isyrun, Beirut: Maktabah alIlmiyah al-Jadidah

Zamakhasyri. 1392 H / 1972 M. al-Kasysyaf, Kairo: Mushthafa al-Babi al-Halabi wa Syirkah

Zarqani. tt. Manâbil al-'Irfân fi 'Ulum al-Qur'an Ttp: Isa al-Bab al-Halabi

Zuhaili, Wahbah ibn Musthafa. tt. al-Fiqh alIslami wa Adillatu, Suria: Dar al-Fikr $1411 \mathrm{H} \mathrm{/}$ 1991 M. al-Tafsir al-Munîr fi al-' Aqidab wa

Fenomena Perkawinan Beda. 
al-Syari'ah wa al-Manhâj, Beirut: Dar al-

Fikr

Zuhri, Muh. 1996. Hukum Islam dalam Lintasan

Sejarah, Jakarta: Raja Grafindo Persada

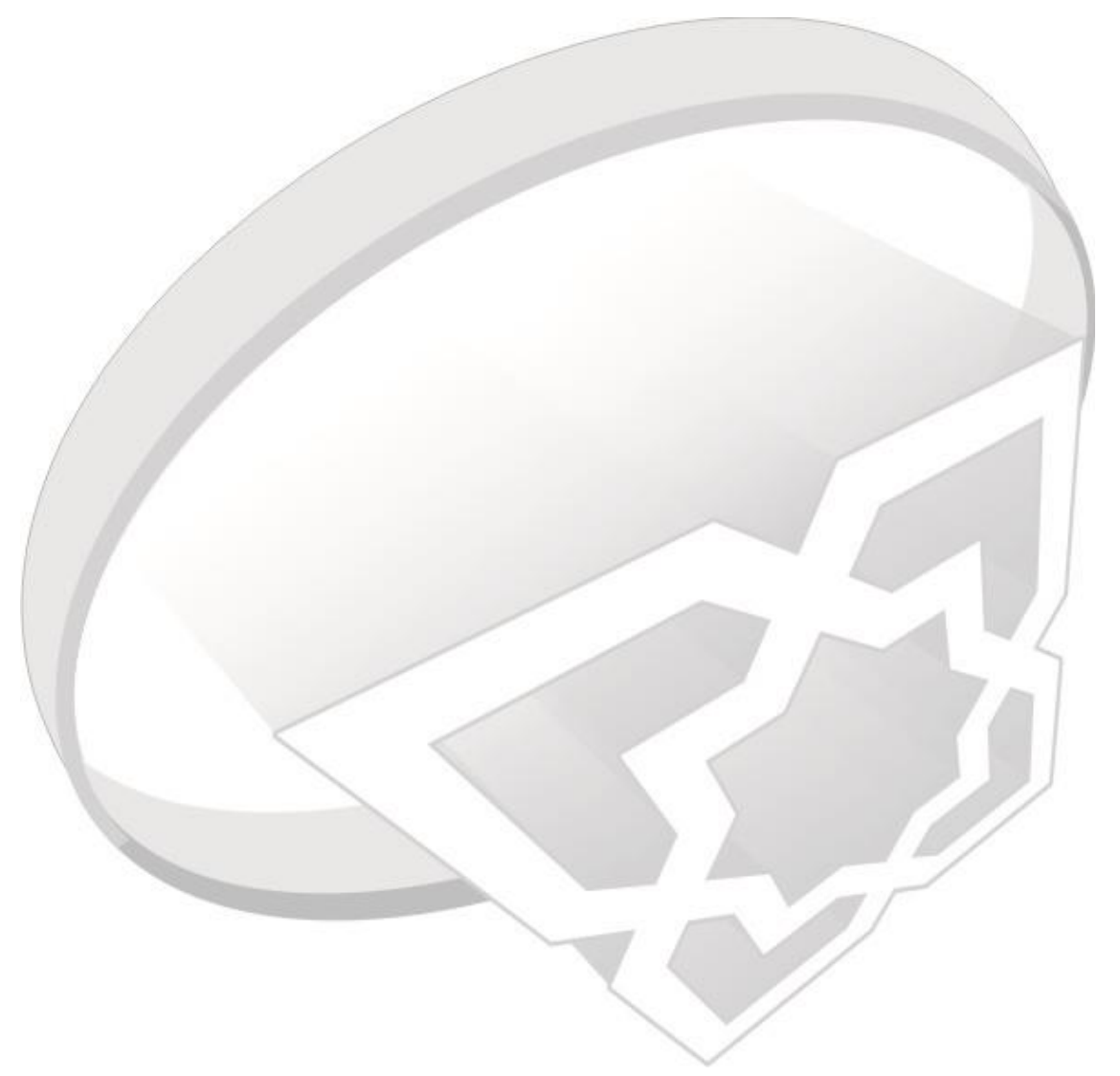

